\title{
Маскулінність без чоловіків (передмова до книжки «Жіноча маскулінність»)
}

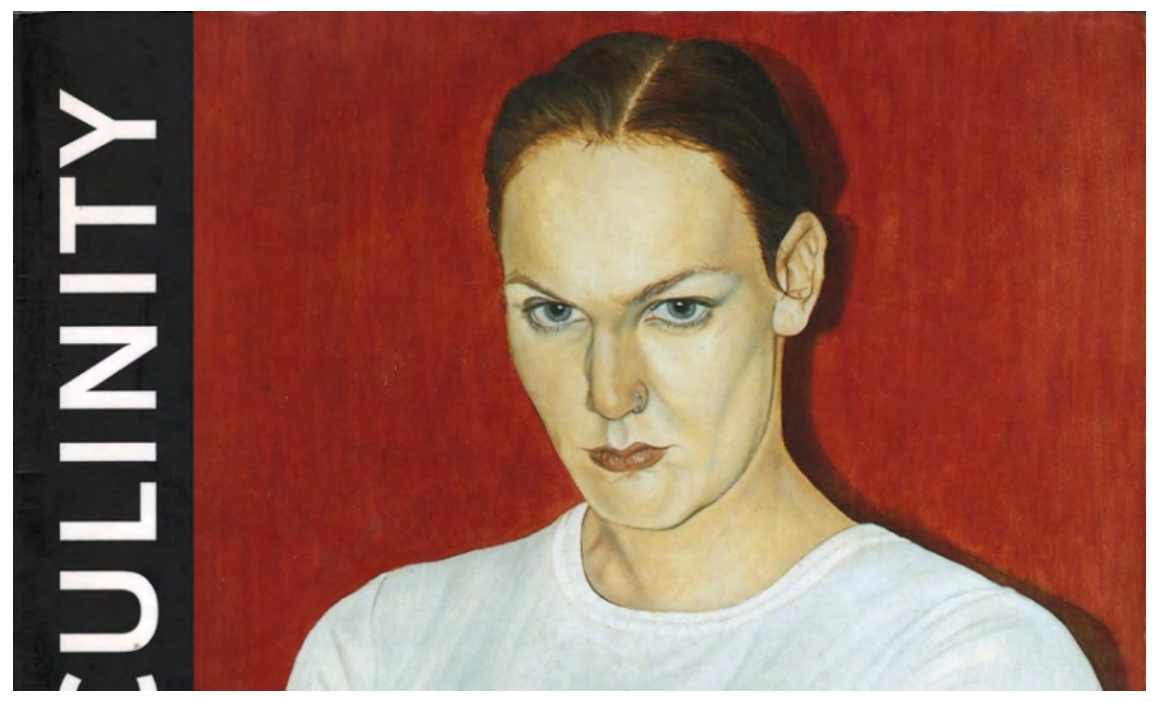

Який сенс бути маленьким хлопчиком, якщо однаково виростеш і станеш дорослим чоловіком?

Гертруда Стайн, «Автобіографія всіх» (1937)

\section{Справжня річ}

о таке «маскулінність»? Протягом п’яти років, що я досліджую жіночу маскулінність, про це в мене запитували найчастіше. Якщо маскулінність - не соціальний чи культурний і навіть

Перекладено за: Judith Halberstam, Female Masculinity (Durkham, London: Duke Univiversity Press, 1998), 1-43. Редакція часопису висловлює вдячність видавництву Duke University Press за дозвіл на переклад вступного розділу (DUP9727). Переклад здійснено в рамках проекту HESP/ReSET «Гендер, сексуальність і влада».

Над цим перекладом разом із нами працювали учасниці перекладацької толоки Ольга Плахотнік, Наталка Чех, Надія Чушак і Галина Ярманова. Ми вдячні нашим товаришкам за глибоке прочитання перекладу, слушні зауваження, цінні коментарі та мовні знахідки. Також я (геo) дякую М. за підтримку та віру в мої сили, навіть коли я в них сумнівалося. - Прим. пер.

На знимці: фрагмент обкладинки першого видання книжки Галберстама «Жіноча маскулінність» (1998).

(C) reо шаровара, Марія Маєрчик, переклад, 2019

(C) Duke University Press, 1998

(c) Критика феміністична: східноєвропейський журнал феміністичних і квір-студій 2019, №2, с. $42-78$ http://feminist.krytyka.com (ISSN 2524-2733) 
не політичний вияв чоловічого тіла, що ж це натомість? Я не вдаватиму, ніби знаю відповідь, проте маю кілька думок, чому не слід зводити маскулінність до чоловічого тіла та його виявів. Також наважуся ствердити, що, хоч означити маскулінність важко, ми як суспільство легко впізнаємо їі та витрачаємо багато часу й грошей, аби підтримувати й зміцнювати звичні, переконливі для нас версії маскулінності; чимало таких «героїчних маскулінностей» сформовано саме через субординацію альтернативних маскулінностей. У цій книжці я стверджую, що жіноча маскулінність не лише не є імітацією чоловічості, а навпаки, вона дає змогу побачити, в який спосіб маскулінність сконструйовано як маскулінність. Інакше кажучи, жіночу маскулінність зображають як негодящу вишкварку домінантної маскулінності саме для того, щоб чоловіча маскулінність могла постати як буцімто справжня. Але те, що ми розуміємо під героїчною маскулінністю, продуковано за допомоги й посередництва як чоловічих, так і жіночих тіл.

Цей розділ - не просто звичайний теоретичний вступ про засади дослідження маскулінності без чоловіків; тут я також роблю огляд міфів і байок про чоловічість, що утверджують невіддільність маскулінності від чоловічого тіла. Задля попередньої спроби переосмислити маскулінність, я запропоную огляд образів альтернативних маскулінностей із художньої літератури та фільмів, а також наведу приклади особистих досвідів. Йтиметься здебільшого про жінок і квір-людей: ці приклади ілюструють, як украй важливо вміти бачити альтернативні маскулінності, а також те, де і коли вони з'являються. У цьому вступі я покажу, як у різний спосіб академічні дослідження маскулінності й культура загалом відверто ігнорують жіночу маскулінність. На мою думку, таке повсюдне нехтування жіночою маскулінністю зумовлено ідеологічними чинниками: воно підтримує систему соціальних структур, покликаних склеювати маскулінність із чоловіком, владою і домінуванням. На моє переконання, послідовний аналіз жіночої маскулінності стане вирішальним утручанням у ґендерні дослідження, студії культури та квір-студії, а також у панівні дискусії довкола гендеру загалом.

Маскулінність у цьому суспільстві незмінно асоціюють із владою, правовласністю та привілеями; часто вона символічно пов'язана із владою держави та нерівним розподілом статків. Назовні вона простягається в патріархат, усередину - у сім'ю; маскулінність репрезентує успадкування влади, результат торгівлі жінками та обіцянку соціальних привілеїв. Певна річ, чимало інших розмежувань змережують терени маскулінності, звужуючи її владу, залежно від переплетіння ознак класу, раси, сексуальності й гендеру. Та коли так звана «домінантна маскулінність» постає в натуралізованому поєднанні чоловічого тіла та влади, марно досліджувати чоловіків задля вивчення конструктів маскулінності. У цій книжці я покажу, що маскулінність стає намацальною як маскулінність саме тоді, коли виходить за межі тіла білого чоловіка середнього класу. Гіпермаскулінність зазвичай ілюструють чорними ті- 
лами (чоловічими та жіночими), тілами латино та латина ${ }^{1}$ й тілами людей робітничого класу, а нестачу маскулінності найчастіше добачають в азійських тілах або тілах людей вищих класів. Ці стереотипні конструювання варіативної маскулінності вказують на процес, як маскулінність набуває домінантності саме тоді, коли її представлено в тілі білого чоловіка середнього класу. I водночас автори багатьох сучасних праць, які прагнуть вивчати конструйованість влади білої маскулінності, усю свою дослідницьку увагу зосереджують не на білих чоловічих тілах, а на вивченні того, яких форм і виявів набуває біле чоловіче домінування. Численні дослідження творчості Елвіса, білої чоловічої молоді, білого чоловічого фемінізму, чоловіків і шлюбу, одомашненої ${ }^{2}$ чоловічості накопичують інформацію про суб'єкта вкрай очевидного й уже добряче обридлого. У моєму дослідженні білість чоловіка, а також маскулінність білого чоловіка, як і вивчення його влади, не перебуватиме в головному фокусі; натомість чоловіча маскулінність фігуруватиме тут як герменевтична, як контрприклад тієї форми маскулінності, яку я вважаю цікавішою у світлі ґендерних взаємодій і продуктивнішою з огляду на просування соціальних змін. У цій книжці я таки вивчаю Елвіса, але тільки у виконанні імперсонаторки Елвіс Герселвіс (Elvis Herselvis)3; політичні обриси чоловічих привілеїв шукаю не в чоловіках, а в житті європейських аристократок-кросдресерок 1920-х років; чоловічо-жіночі відмінності відстежую, порівнюючи не чоловіків і жінок, а буч-лесбійок i FtM-транссексуалів ${ }^{4}$; чоловічі іконічні образи розглядаю на прикладі не кінематографічних кумирів, а репрезентації бучів у кіно; зрештою, показую, що форми й образи модерної маскулінності найкраще продемонстровано взірцями жіночої маскулінності.

Добрим початком для книжки про жіночу маскулінність може бути спроба розвінчати визнану чоловічу кінематографічну ікону - Бонда, Джеймса Бонда. Аби проілюструвати ідею про те, що модерна маску-

\footnotetext{
1 Латино та латина - поширені в Північній Америці самоназви осіб латиноамериканського походження, де латино (англ. Latino) позначає чоловіків, а латина (англ. Latina) - жінок. В оригіналі Галберстам вживає вираз «latino/a bodies». - Прим. пер. 2 Тут одомашнення [domestication] стосовно чоловіків означає дискурсивну практику із залучення їх у приватний, «родинний простір», особливо після воєн; спробу переозначити «еталон» маскулінності через роль чоловіка та батька, господаря. Прим. пер.

3 У цьому сценічному імені обіграно смисл, який вказує на жіночий рід персонажки. Його можна передати як «Елвіс, яка вона є», «Елвіс власною персоною». - Прим. пер. ${ }^{4}$ У перекладі ми залишаємо оригінальну авторську термінологію. Проте зауважимо, що терміни транссексуал* і транссексуальність сьогодні вже застаріли, їх вважають виразниками медичного дискурсу, що довший час розглядав трансгендерність як хворобу або патологію. Те саме стосується усталених і широко використовуваних абревіатур FtM [female-to-male] та MtF [male-to-female], які дослівно можна перекласти «з жінки в чоловіка» та «з чоловіка в жінку». Проблемність їх у тому, що вони оперті на бінарну систему гендеру, посилюють їі, а також містять у назві небажаний для людини гендер як вихідний, з яким людина могла ніколи себе не асоціювати. Прим. пер.
} 
лінність найкраще представлена жіночою маскулінністю, розгляньмо бойовик про Джеймса Бонда, де чоловіча маскулінність часто постає як тьмяний відблиск набагато більш справжньої та переконливої альтернативної маскулінності. Скажімо, у фільмі «Золоте око» («GoldenEye», 1995) Бонд, як то завжди, б'ється $з$ поганими пацанами: з усілякими комуняками, нациками, торгашами і з однією суперагресивною войовничою персонажкою. Бонд діє у звичній для нього манері галантного й ризикового героя бойовика, маючи свій типовий набір пристроїв: пасок із втяжним тросом, кулькову ручку-бомбу, лазерний бойовий годинник тощо. Та все ж у фільмі бракує чогось сутнісного, а саме - переконливої маскулінної влади. Шефиня головного героя, промовистий буч М. у літах, називає Бонда динозавром і різко критикує його за мізогінію та сексизм. Секретарка міс Маніпенні звинувачує його в сексуальних домаганнях, приятель зраджує і називає дурником, а жінки, схоже, не піддаються його чарам: поганий костюмчик і численні сексуальні інсинуації так само застаріли й утратили ефективність, як і самі Бондові пристрої.

У цьому радше недобойовику маскулінність здебільшого $є$ штучною: як і в інших численних бойовиках, вона мало пов'язана з біологією чоловічого тіла і частіше позначена технічним спецефектом. Найпереконливішу маскулінність у фільмі демонструє М., і досягає вона цього, частково викриваючи фальшивість Бондового перформансу. Саме М. переконує нас, що сексизм і мізогінія не є невилучними складниками маскулінності, хоча з історичної перспективи важко й заледве можливо відокремити маскулінність від пригнічення жінок. Герой пригодницького бойовика, здавалося б, мусить демонструвати досконалу форму нормативної маскулінності, натомість ми спостерігаємо, як перебільшена маскулінність стає радше пародією чи розвінчанням норми. Позаяк маскулінність як таку зазвичай вважають природним ґендером, цей бойовик, з його акцентом на штучних пристроях, власне, підважує гетеросексуальність героя, хоч і посилює його маскулінність. У фільмі «Золоте око», скажімо, Бондову маскулінність причеплено не лише до цілковито неприродної форми чоловічого втілення, а й до гей-маскулінності. У сцені, де Бонд прийшов отримати свої супернові пристрої, їх йому вручає і з ентузіазмом демонструє промовисто манірний науковець-ботан із невипадковим іменем Аґент К'ю (Agent Q) ${ }^{5}$. Аґент К'ю $є$ чудовим прикладом взаємопроникнення квірних і домінантних режимів: саме К'ю і є агентом, він є квірним суб'єктом, який увиразнює, як постає домінантна гетеросексуальна маскулінність. Гей-маскулінність Аґента К’ю та жіноча маскулінність М. вияскравлюють цілковиту залежність домінантної маскулінності від міноритарних маскулінностей.

Якщо в Бонда відібрати його іграшки, йому вже не буде чим підтримати свій перформанс маскулінності. Без лискучого костюма, півусміш-

\footnotetext{
${ }^{5}$ Кодове ім'я Аґент К'ю (Agent Q) натякає на його ненормативність, адже $q$ - від англ. queer (квір). - Прим. пер.
} 
ки, запальнички, що трансформується в лазерний пістолет, наш Джеймс лишається героєм без звитяг і пригод. У фільмах про Бонда маскулінність білого чоловіка - назвімо ії «епічна маскулінність» - повністю залежить від підпільної мережі секретних урядових груп, добре фінансованих науковців, армії, а також від незліченних вродливих поганих і хороших красунь; i, певна річ, вона залежить від миттєво впізнаваного «поганого пацана». Образ «поганого пацана» $€$ типовою жанровою складовою наративів про епічну маскулінність: згадаймо хоча б «Утрачений рай» («Paradise Lost») з есхатологічним розмежуванням між богом і дияволом; сатана, можна сказати, був прообразом поганого пацана. Маскулінність поганого пацана зовсім не перешкоджає йому мати доступ до чоловічих привілеїв - навпаки, погані пацани цілком можуть видаватися переможцями, зазвичай вони просто помирають швидше. Тепер навіть $\epsilon$ лінія одягу «Поганий хлопець» («Bad Воу»), яка використовує стилістику поганого пацана, і це показує, як швидко виклик перетворюється на звичайнісіньке споживання, коли йдеться про білих чоловіків. Ще один бренд, що потурає споживацькому потенціалу чоловічого бунтарства, - спортивний одяг «Без страху» («No Fear»). Реклама цього бренду зображає чоловіків, що займаються скайдайвінгом, серфінгом, автоперегонами, де вони демонструють маскулінність у той спосіб, що в одязі з лого «Без страху» виконують смертельні трюки задля розваги на дозвіллі. Щоб пересвідчитись, наскільки насправді одомашнено цей бренд, досить уявити, що може для жінок означати «без страху»? Це означає вміти стріляти з вогнепальної зброї, тренуватися чи навчатися бойовим мистецтвам, але це навряд чи означало б пірнати в небо. Тож очевидно, що «Без страху» $\epsilon$ розкішшю, і в жодному випадку його не слід прирівнювати до якої-небудь форми соціального бунту.

Існує також тягла літературна та кінематографічна історія возвеличення чоловічої непокори. Тут Джеймс Стюарт (James Stewart), Грегорі Пек (Gregory Peck) і Фред Астер (Fred Astaire) є прикладами втілення добрих пацанів, а Джеймс Дін (James Dean), Марлон Брандо (Marlon Brando) і Роберт Де Hipo (Robert De Niro) представляють образи поганих пацанів, однак на ділі доволі складно розмежувати ці дві групи. Скажімо, у 1950-х роках образ поганого пацана містив риси білого представника робітничого класу, який бунтує проти суспільства середнього класу й певних форм одомашнення; проте сьогоднішній бунтар без ідеалу ${ }^{6} \epsilon$ завтрашнім інвестиційним банкіром, а чоловічий бунт часто завершується вибором на користь респектабельності, адже винагорода за конформність швидко перевищує винагороду за соціальний спротив. Перефразовуючи Гертруду Стайн (Gertrude Stein), який сенс бути хлопчиком-бунтівником, якщо однаково виростеш і станеш дорослим чо-

\footnotetext{
${ }^{6}$ Тут Галберстам вочевидь апелює до назви фільму Ніколаса Рея «Бунтар без ідеалу» або «Бунтар без причини» («Rebel Without a Cause», 1955). - Прим. пер.
} 
ловіком? Безумовно, щойно бунтівник перестає бути білим чоловіком середнього класу (індивідуалізованою окремою персоною чи навіть узагальненим членом хлоп'ячої банди) і стає бунтівником класовим або расовим, виникає зовсім інша загроза.

\section{Пацанки [Tomboys]}

А що як хлоп'ячий бунт виявиться не тестостероновмісною либою хулігана, а глузуванням пацанки? Пацанковістю зазвичай називають подовжений дитячий період жіночої маскулінності. Якщо довіряти загальному розумінню дитячої поведінки, хлопчакуватість $є$ доволі типовою для дівчаток і не спричиняє батьківського занепокоєння. Оскільки аналогічні випадки крос-ґендерної поведінки хлопчиків повсякчас викликають істеричну реакцію, може здатися, буцім жіночу ґендерну девіантність суспільство толерує більше, ніж чоловічу (Halberstam 1999). Не певен, чи це можна вважати ознакою толерантності і чи реакція на дитячу ґендерну поведінку бодай щось каже про межі дозволеного в дорослій чоловічій і жіночій ґендерній поведінці. Пацанковість зазвичай асоціюють із «природним» бажанням мати більше свободи й бути мобільною, як хлопці. Дуже часто її сприймають як вияв незалежності й цілеспрямованості, тому пацанковість можуть навіть заохочувати тою мірою, доки вона гармонійно поєднана із сталим усвідомленням себе дівчинкою. Однак за пацанковість карають, щойно вона стає ознакою надмірного ототожнення себе із чоловіком (використання хлоп'ячого імені або цілковита відмова від дівчачого одягу) і загрожує не завершитися, а тривати в підлітковому віці ${ }^{7}$. Підліткова пацанковість становить проблему і зазнає найжорсткіших форм виправлення. Скажімо так, пацанковість толерують, доки дитина не досягнула статевої зрілості; та щойно настає пубертатний вік, дівчата відразу підпадають під тиск ґендерної конформності. Вимога ґендерної комформності стосується всіх дівчат, не лише пацанок, і з цього моменту вже важче стверджувати, буцім чоловіча фемінність становить більшу загрозу соціальній чи сімейній стабільності, ніж жіноча маскулінність. Жіноча підлітковість $€$ переломним моментом у зростанні дівчинкою в чоловікоцентричному суспільстві. Якщо для хлопців дорослішання ознаменується ритуалом переходу (який західна література оспівала у формі роману-виховання) і набуттям певної, хоч і малоефективної, соціальної влади, то для дівчат дорослішання - це урок покори, покари й пригноблення. Саме в підлітковому віці пацанкові нахили мільйонів дівчат переробляють на задовільні для суспільства форми фемінності.

Дивовижно, що бодай дехто з підліток таки виростають маскулінними жінками. Формуванню маскулінності в молодих жінок почасти

\footnotetext{
${ }^{7}$ Більше про покарання пацанок можна прочитати в дослідженні Филіс Берк, де авторка аналізує випадки так званих розладів ґендерної ідентичності [Gender Identity Disorders], коли дівчаток відучували від «хлоп'ячої» поведінки та привчали до строгих форм жіночості (Burke 1996).
} 


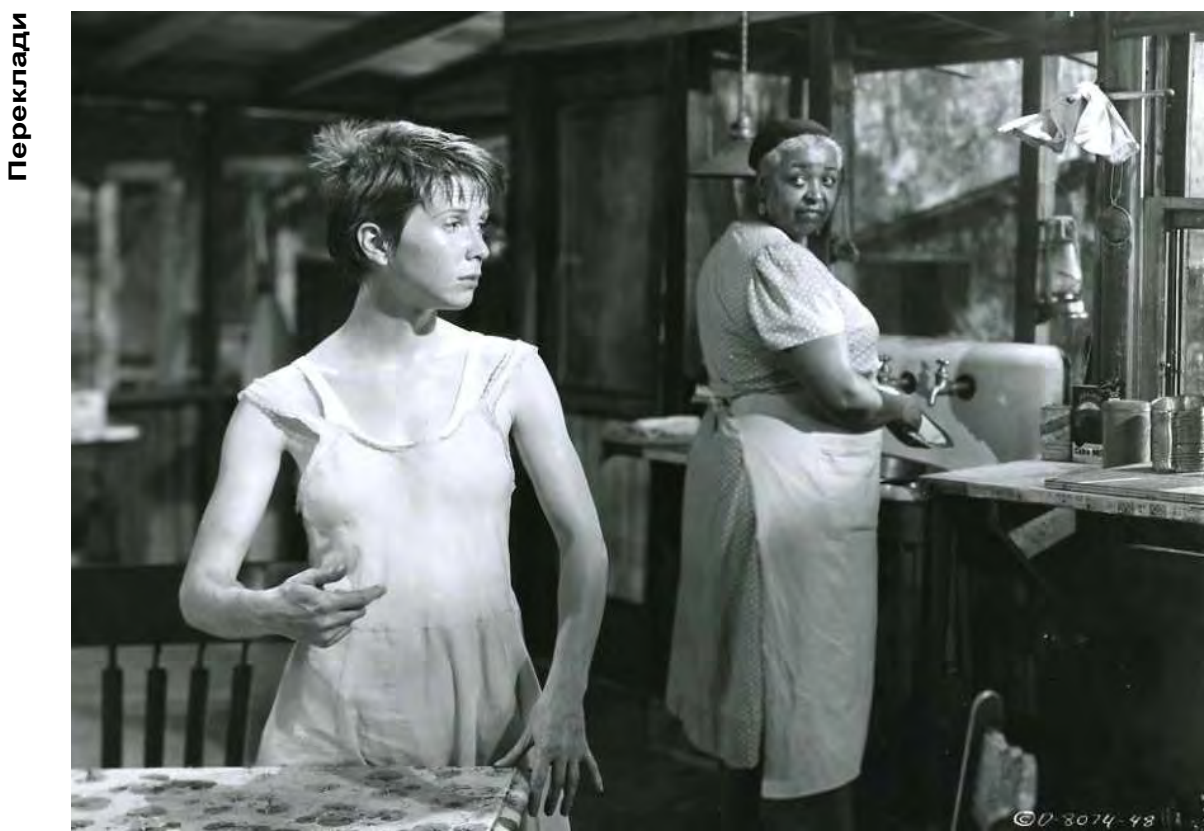

«Не входила в жодне товариство, узагалі ні в що не була залучена». Джулі Гаріс у ролі Френкі Адамс та Етель Вотерз у ролі Берніс у фільмі Фреда Цинемана «Учасниця весілля» (1953)

сприяють щораз видиміші та визнаніші лесбійські спільноти. Але, як свідчить навіть побіжний огляд популярних кінострічок, образ пацанки толеровано тільки в контексті наративу про розквіт жіночності; у цих наративах хлопчакуватість $є$ спротивом дорослості як такій, але не дорослій фемінності. У романі Карсон Мак-Калерс «Учасниця весілля», а також у фільмі, знятому на основі цього класичного пацанківського наративу, пацанка Френкі Адамс вступає в програшну війну із жіночістю, а текст зображає жіночість, або ж фемінність, як кризу репрезентації, що не пропонує героїні задовільного для неї вибору.

Напередодні братового весілля Френкі заявляє, що почувається чужою, не залученою в символічне весільне товариство, не причетною до жодної з категорій, через які її можна було б описати. Мак-Калерс пише: «Ця історія відбулася одного божевільного зеленого літа, коли Френкі було дванадцять. На той час вона вже тривалий час ні в чому не брала участі. Не входила в жодне товариство, узагалі ні в що не була залучена. Неприкаяна, Френкі тинялася біля чужих одвірків, і їй було страшно» (McCullers 1946, 1). Мак-Калерс показує Френкі на зорі підлітковості («коли Френкі було дванадцять»), у період тривалої «незалученості»: «Не входила в жодне товариство, узагалі ні в що не була залучена». Хоч дитинство загалом можна вважати періодом «неналежності», та хлопчакувату дівчинку, яка стоїть на порозі жіночності, статус «незалученості» робить мішенню для різних видів соціального насилля й осуду. Із 
завершенням безтурботного дитинства Френкі Адамс стала пацанкою, яка «тинялася біля чужих одвірків, і їй було страшно».

Жанр фільмів про пацанок, як я покажу в шостому розділі «Виглядати бучно», постулює думку, що доступні для жінок означники расової, гендерної та сексуальної належності є незадовільними. Мак-Калерс у своєму романі демонструє, що ця незадовільність $\epsilon$ прямим наслідком тиранії мови - структури, яка штучно, проте міцно фіксує людей і речі на визначених місцях. Френкі прагне змінити свою ідентичність, змінивши ім'я: «Чому закон не дозволяє змінити ім'я?», - запитує вона в Берніс. А та відповідає: «Тому що речі зосереджуються довкола твого імені», й наголошує, що без імен запанував би хаос «і світ з'їхав би з глузду» (McCullers 1946, 107). Водночас Берніс визнає, що зумовлена іменами непорушність полонить людей у розмаїті ідентичності, расові та гендерні: «Усі ми так чи так припнуті... Може, ми й хотіли б розправити крила і бути вільними. Але що не роби, а ми залишаємось ув'язненими» (McCullers 1946, 113). Френкі вважає, що в називанні виявляється влада давати визначення, а зміна імені дає змогу перевинайти ідентичність, місце, взаємини й навіть ґендер. «Цікаво, чому закон забороняє змінити ім'я, - міркує Френкі. - Або взяти ще одне... Та й біс із ним!.. Ф. Джезмін Адамс» (McCullers 1946, 15).

Психоаналіз постулює тісну пов'язаність мови й бажання, де мова структурує людські бажання i, таким робом, показує їхню невичерпність і водночас недосяжність. Невичерпність - бо ми постійно бажаємо, а недосяжність - бо ми ніколи не буваємо задоволеними. Френкі, зокрема, розуміє, що бажання й сексуальність $є$ найрегламентованішими формами соціальної комформності, згідно з якою ми повинні жадати лише певних людей і лише в певний спосіб, однак її бажання так не працює, і вона розривається між своїм бажанням та своєю належністю. Позаяк Френкі бажає в неправильний спосіб, вона вирішує уникати бажання взагалі. Ії̈ боротьба з мовою, спроби змінити себе через зміну імені, а світ - через новий спосіб буття, є героїчними, однак провальними. Песимізм Мак-Калерс пов'язаний із відчуттям нездоланності «порядку речей», якого не змінить одна людина і який працює через такі засадничі речі, як мова, силуючи незалучених до не підхожої їм залученості.

У цій книжці я відкидаю уявлення про пацанківський наратив як несерйозний, натомість користуюся можливістю, аби визнати й ствердити по-іншому гендеровані тіла й суб'єктності. Я залучаю в дослідження джерела XIX століття та новочасні, вивчаю щоденники, судові справи, романи, листування, фільми, перформанси, події, критичні статті, відео, новинні повідомлення й персональні свідчення та закликаю створювати нові таксономії - «таксономії-оказіоналізми» [nonce taxomomies], як їх дотепно називає Ів Косовскі Седжвік в «Епістемології комірчини» («Epistemology of the Closet») ${ }^{8}$, класифікації бажання, тілесності й суб’єк-

${ }^{8}$ В американському і британському сленґах «nonce» також є старим сленґовим словом на позначення збоченства. - Прим. пер. 
тності, що прагнуть порушити гегемонну процедуру називання та визначення. Таксономії-оказіоналізми є категоріями, які ми використовуємо щоденно для осмислення своїх світів, але це відбувається гладко і для нас майже непомітно. Тожу цій книжці я спробую оприявнити деякі таксономії-оказіоналізми жіночої маскулінності й дослідити історію їх пригнічення. Тут і надалі за допомогою теми жіночої маскулінності я вивчаю феномен квір-суб'єкта, який здатен успішно підважити гегемонні моделі ґендерної конформності. Жіноча маскулінність $є$ особливо цікавим предметом дослідження, адже їі однаково шельмують і гетеросексистські, і феміністичні/вуманістські ${ }^{9}$ підходи; на відміну від чоловічої фемінності, яка виконує в чоловічих гомосоціальних культурах щось на кшталт ритуальної функції, жіночу маскулінність зазвичай інтерпретують в гетеро- та гомонормативних культурах як патологічний випадок хибної самоідентифікації та дезадаптації, як бажання бути владою і мати владу, якої вона, втім, завжди позбавлена. У контексті лесбійства жіночу маскулінність розглядають як місце, де патріархат попрацював із жіночою психікою і витворив внутрішню мізогінію. Й донині ще $\epsilon$ напрочуд мало досліджень і теорій про неуникний вплив добре артикульованої жіночої маскулінності на, здавалося б, непорушну чоловічу маскулінність. Часом жіноча маскулінність і справді дуже подібна на показну чоловічу зверхність, проте інколи вона $є$ прикладом унікальної форми соціального бунту; часто вона $€$ ознакою сексуальної відмінності, але іноді позначає варіант гетеросексуальності; подеколи жіноча маскулінність $€$ ознакою патології, однак за інших обставин вона $\epsilon$ здоровою альтернативою тому, що ми вважаємо награною конвенційною фемінністю.

Я хочу створити таку модель жіночої маскулінності, що відображала би багато різних їі форм, але водночас відкривала б можливість нових свідомих самостверджень і різних ґендерних таксономій. Такі самоствердження беруть початок не з підриву маскулінної влади чи опонування їй, а з відмови зважати на конвенційні маскулінності й приймати їх. Наприклад, бунт Френкі Адамс полягає не в спротиві закону, а в байдужості до нього; так, вона розуміє, що змінити чи подовжити своє ім'я - незаконно, проте має на це просту відповідь: «Та й біс із ним». У цій книжці я не пропоную рухатися непродуктивним шляхом, що його Фуко назвав «казати владі “ні”», однак стверджую, що влада може бути присутньою в різних формах відмови: «Та й біс із ним».

\section{Квір-методології}

Щоб дослідити множинні форми ґендерної невідповідності в межах жіночої маскулінності, у цій книжці я вдаюся до кількох методологій. Зважаючи на міждисциплінарність мого дослідження, я створюю ме-

\footnotetext{
${ }^{9}$ Вуманізм - одна з течій «чорного» фемінізму, для якої наріжним каменем $є$ пригноблення чорних/небілих жінок за ознаками раси й класу. Авторкою терміна $є$ письменниця Еліс Вокер. - Прим. пер.
} 
тодологію з доступних дисциплінарних методів. Те, що я тут називаю «квір-методологією», є поєднанням критичного аналізу текстів, етнографії ${ }^{10}$, історичних студій, архівних досліджень і творення таксономій. Я називаю цю методологію «квір», бо вона прагне бути чутливою до різних джерел інформації про жіночу маскулінність і виявляє певну нелояльність до конвенційних дисциплінарних методів. Певна річ, зосередження лише на художніх текстах уможливило б методологічну цілісність, але застосована тут квір-методологія, власне, є тією формою відмови, про яку йшлося наприкінці попереднього параграфа.

Хоча найцікавіші дослідження альтернативних сексуальних спільнот виконано у формі етнографії, а джерелами для вивчення сексуальних ідентичностей нерідко стають автобіографії та наративні історії, квір- дослідниці і дослідники не дійшли згоди, як слід збирати й аналізувати інформацію про сексуальну ідентичність. Найгостріші і найтриваліші дискусії у квір-студіях точаться довкола питань дисциплінарності й методології. У студіях культури стверджують, що соціологічні методи збору, обробки та презентації даних про сексуальність, тобто опитування й інші методи соціальних досліджень, радше перевідкривають наперед відомі сексуальні системи, а не виявляють щось досі невідоме; тимчасом у соціальних науках уважають, що студії культури приділяють мало уваги матеріальним аспектам квір-життя. I хоч в академії без упину тривають розмови про важливість міждисциплінарних студій, загалом до таких робіт в університетах ставляться не надто схвально. Тож моє дослідження може зазнати критики і з боку історичних наук за брак історичності, і з боку літературознавства - за розгляд не лише художніх текстів, і з боку соціальних студій - за відмову від традиційних методів соціології. I хоч я не знімаю з себе відповідальності за помилки, що могли виникнути під час написання роботи, також я розумію, що моє дослідження оприявнює проблему, яка постала перед квір-студіями загалом: як нам створити квір-методології за лавами традиційних університетських кафедр?

Створюючи квір-методологію, я повністю відмовляюся принаймні від одного методу дослідження сексуальності - від традиційного соціологічного опитування, яке має на меті вичавити істину з первинних даних. У рецензії про низку нових соціологічних опитувань для «Нью-Йоркського книжкового огляду» Ричард Левонтин прокоментував проблеми соціологічного підходу до сексуальності: «3 огляду на соціальні особливості сексуальної активності, схоже, єдиний спосіб довідатися, що люди роблять “у ліжку”, - запитати їх. Але їхні відповіді теж не варто сприймати за чисту монету» (Lewontin 1995, 24). Левон-

\footnotetext{
10 Тут і надалі слово «етнографія» вжито у значенні методу збору емпіричного матеріалу (як цей термін уживають у західноєвропейській і північноамериканській академічній традиції), а не в значенні дисципліни (яке звичніше для пострадянської академії). - Прим. пер.
} 
тин зауважує, що свідчення людей не $є$ надто надійними, коли йдеться про їхню сексуальну активність (наприклад, чоловіки її перебільшують, а жінки - применшують), і в межах соціологічних методів немає способу робити поправку на такі особливості. Однак у соціології не переймаються таким високим рівнем неправдивих даних про сексуальність і все завзяття скеровують на вирішення методологічних проблем. Левонтин підсумовує, і тут, гадаю, він має рацію, що соціологічне опитування «є демонстрацією того, що його виконавиці чи виконавці вважали правдою» (Lewontin 1995, 25). У час, коли до гуманітарних дисциплін ставляться з недовірою, важливо вказувати, що методи соціальних наук опираються на наративний аналіз, інтерпретацію й умоглядні побудови. Як підсумовує Левонтин: «Якими мають бути соціальні науки? Відповідь, певно, полягає в тому, що їм треба бути менш гоноровими й облишити перетворювати соціологію на різновид природничих наук, хоча вона й вивчає природні об'єкти» (Lewontin 1995, 29). Утім, я не хочу сказати, що традиційні соціологічні методи зовсім не годяться. На деякі питання щодо сексуальності можна відповісти лише завдяки методу опитування (наприклад, скільки лесбійок використовують кофердам ${ }^{11}$ ? До якої вікової групи та соціального класу належать такі лесбійки?), але, на жаль, надто часто опитування використовують, аби зібрати не настільки фактологічну інформацію, і тоді всі тонкощі й нюанси втрачаються ${ }^{12}$.

Якоюсь мірою парадоксально, що традиційні соціологічні методи не підходять для вивчення сексуальності, адже, як часто наголошують у квір-соціологічних студіях, чимало теоретичних систем, які ми використовуємо для дослідження сексу, як-от соціальний конструктивізм, прийшли із соціології. У новому «квірному» числі «Соціологічної теорії» зроблено спробу проаналізувати складні взаємини соціології та квір-теорії. Стівен Епстин зазначає, що саме соціологія вказала на соціальну конструйованість сексуальності: «Не хочу применшувати важливості інших дисциплін, проте, як на мене, і квір-теорію, і ґей-лесбійські студії, як ми їх знаємо сьогодні, годі уявити без внеску соціологічної теорії» (Epstein 1994,189). Арлін Стайн і Кен Пламер розвивають думку Епстина і критикують сучасний стан квір-теорії: «Квір-теоретики... беруть до уваги вплив літературних текстів і масової культури на сексуальність, однак їхнім слабким місцем $є$ зосередження майже винятково на тек-

\footnotetext{
${ }^{11}$ Кофердам - латексні серветки, бар'єрний засіб для орального сексу. - Прим. пер.

${ }^{12}$ Дякую Естер Ньютон (Esther Newton) за цю ідею й пояснення, за яких обставин ці методи таки можуть бути корисними. Приклади запитань для дослідження сексуальності можна переглянути тут: Gagnon 1994. Ця книжка є показовою тим, що відкриті запитання про сексуальні практики в ній скеровано виключно на пари. Крім того, це дослідження чітко пов'язує певні практики з певними ідентичностями. Наприклад, питання щодо анального сексу ставлять тільки парам чоловік - жінка та чоловік - чоловік, адже анальний секс визначено як «проникнення чоловічого пеніса в анус/пряму кишку партнера» (Gagnon 1994, 260). Відповідний розділ не містить запитань до пар жінка - жінка, запитань про секс-іграшки, використання фалоімітаторів або рук.
} 
стах. Це небезпечна тенденція, притаманна новим квір-теоретикам, ігнорувати "реальне" квірне життя в його матеріальних досвідах по всьому світу, натомість бавитися самоцільними означниками текстів» (Plummer and Stein 1994, 184).

Намагаючись повернути соціології належне їй місце у справі вивчення сексуальності, Стайн і Пламер знову чітко окреслили різницю між реальним і текстуальним: текстуальний аналіз вони означують як обмежений, позбавлений референта, матеріальних наслідків та інтелектуальних здобутків. Але, як зазначає Левонтин у рецензії, саме ця відмежованість реального й матеріального від представленого й текстуального і становить проблему для кількісного дослідження. Задля справедливості скажу, що Стайн і Пламер не пропонують просто вдатися до кількісних методів у дослідженнях сексуальності і квір-субкультур, але певною мірою вони таки відтворюють сутнісне розмежування на правду про сексуальну поведінку та вигадку текстуального аналізу.

Я веду до того, що відповідь на питання, як досліджувати сексуальність, почасти криється в міждисциплінарному підході, здатному поєднувати інформацію від людей з інформацією із текстів. I хоча, наприклад, Сінді Петтон у «Тремти, Гетеросвине» розчаровано говорить про домінування «текстуально орієнтованих форм квір-теорії», мусимо замислитися, чи існує взагалі квір-теорія або теорія сексуальності, не текстуально орієнтована? (Patton 1993, 165). Хіба в етнографії сексуальності вивчають не тексти? А в соціальній історії хіба не з текстів беруть дані? Це можуть бути тексти усної історії, матеріали інтерв'ю, художні тексти чи автобіографії, але з огляду на визначальну обставину, що секс $\epsilon$ ділом «приватним» і відбувається без сторонніх, немає способу проводити спостереження безпосередньо «в спальні». І навпаки, читання текстів вимагає також знання історичних контекстів і певної причетності до реального досвіду суб’єктів. Методології, грунтовані на текстах, хибують на надмірну абстрактність, а соціальні науки хибують на надмірну раціоналізацію сексуальної поведінки. Врешті-решт, хоч літературознавчі та культурологічні підходи до конструювання ідентичності й критикують за аполітичність і неісторичність, однак теорії, які безпосередньо пов'язують історію сексуальності з економікою чи рухом капіталу, створюють точнісінько такі самі лінійні наративи раціонального прогресу й модернізації, яким сексуальність, схоже, чинить опір.

У певному сенсі квір-методологія є методологією-посмітюхою: вона застосовує різні методи, щоб зібрати інформацію і створити знання про людей, яких було умисне чи випадково виключено з традиційних досліджень людської поведінки. Квір-методологія намагається поєднати методи, що їх часто вважають непоєднуваними, й ігнорує академічний примус до дисциплінарної когерентності. Хоча цю мою книжку розглядатимуть як дослідження зі студій культури, я не цураюся й емпіричних етнографічних досліджень. 


\section{Конструювання маскулінності}

Останнім часом маскулінність стала улюбленою темою студій культури. Тут я хочу поміркувати про дедалі популярніші дослідження маскулінності, які не виявляють жодного зацікавлення маскулінністю без чоловіків. Безпрецедентну увагу до маскулінності я зауважив у квітні 1994-го, коли Центр театральних мистецтв при Детройтському інституті мистецтв (DIA Center for Performing Arts) запросив когорту знаних інтелектуалок й інтелектуалів до дискусії на цю тему. На відкритті конференції учасник запитав: «Чому маскулінність і чому зараз?» Кілька інших чоловіків, критиків і науковців, виголосили яскраві промови про дитинство та взаємини з татами. Під час панельної дискусії поетка-лесбійка прочитала сумний вірш про згвалтування. I лише наприкінці вечора одна особа указала на обмеженість такої розмови, що інтерпретує «маскулінність» як синонім до «чоловіка» чи «чоловічості» ${ }^{13}$. Це одиноке втручання оприявнило розрив між панівними дискусіями щодо маскулінності й чоловіків і сучасними квір-дискусіями про маскулінність, які сягають далеко за межі чоловічого тіла. Адже на наївне запитання того вечора: «Чому маскулінність і чому зараз?» - можна було відповісти: «Тому що в 1990-х маскулінність нарешті інтерпретують, бодай почасти, як конструйовану і людьми, народженими як жінки, і людьми, народженими як чоловіки» ${ }^{14}$.

Публікація виголошених на конференції доповідей ще виразніше продемонструвала, як безальтернативно упорядники збірки ототожнювали маскулінність із чоловічою статтю. На обкладинці збірки розміщено невеличке фото реклами крамниці одягу зі слоганом «Спорядження для чоловіків» («Fixing for Men»). Ця ілюстрація, розміщена під заголовком «Конструювання маскулінності», спонукає нас розуміти творення маскулінності як культурно зумовлене оснащення осіб чоловічої статі одягом. У вступі упорядники зробили спробу урізноманітнити таке визначення маскулінності, згадуючи дописи Джудит Батлер та Ів Седжвік, вони визнали виклики, що їх ґеї, лесбійки та квір-люди кинули категоріям ґендерної нормативності. Упорядники стверджують, мовляв, маскулінність $€$ множинною, «це не тільки про чоловіків; ідея маскулінності стосується, формує та форматує всіх» (Berger, Wallis and Watson 1996, 7). Розуміння маскулінності як множинної представлено

\footnotetext{
${ }^{13}$ Матеріали конференції опубліковано в збірці «Конструювання маскулінності» (Berger, Wallis, and Watson 1996), авторкою інтервенції щодо нечоловічих маскулінностей $\epsilon$ Ів Косовскі Седжвік.

${ }^{14}$ Я вживаю поняття «люди, народжені як жінки» [female-born people] та «люди, народжені як чоловіки» [male-born], щоб указати на соціальну практику приписувати немовлятам один із двох гендерів при народженні. Така термінологія дає змогу зауважити, що людина може впродовж цілого свого життя не визнавати цих приписувань і що гендерна бінарність від початку домінує в наших культурних і наукових визначеннях ґендеру, хоча завжди є люди, які не можуть знайти себе в жодній із двох опцій.
} 
в тексті першого есею Ів Седжвік, де зазначено, що маскулінність мало стосується чоловіків; далі цей погляд трохи розвиває Джудит Батлер в есеї «Меланхолійний ґендер» («Melancholy Gender»). Але Седжвік також критикує упорядників збірки й організаторів конференції про маскулінність за послідовне зв'язування маскулінності та чоловічої статі. Хоч у вступі упорядники запевняють авдиторію, буцім узяли до уваги ідеї Седжвік про гендерне розмаїття, решта збірки цього не потверджує. У виданні $\epsilon$ чимало добрих текстів, однак про жіночу маскулінність жодного. Також у вступі не згадано про використані для оформлення збірки ґендер-квірні роботи Лорен Кемерон (Loren Cameron) і Кеті Опі (Cathy Opie). Натомість у текстах багато уваги приділено дискусіям про образи кумирів-чоловіків, як-от Клінт Іствуд і Стивен Сигал, роздумам про складні взаємини між батьком і сином, дослідженню про те, як наука, наприклад, означує чоловіків, маскулінність і закон. Завершує збірку есей Стенлі Ароновіца «Моя маскулінність» (Stanley Aronowitz «My Masculinity») - автобіографічний огляд різних форм чоловічої влади.

Усе це не означає, що збірка нецікава чи есеї у ній невідповідні. Я тільки хочу сказати, що задекларована на початку редакторська ідея не $\epsilon$ прологом до текстів, вона радше $\epsilon$ епілогом про те, якою збірка про маскулінності мала би бути, але не стала. Хоч необхідність досліджувати жіночу маскулінність тут визнано, та, схоже, таки важко реалізувати таке завдання. Перефразовуючи есей Ів Седжвік: чому не встановлювати апріорного есенціалістичного зв'язку між маскулінністю і чоловіками виявилося таким складним завданням ${ }^{15}$ ?

Цим оглядом конференції «Конструюючи маскулінності» та збірки статей я не хочу сказати, буцім тему жіночих маскулінностей конче треба розглядати в ширшому контексті, серед інших маскулінностей, що були і все ще $\epsilon$ пов'язані із чоловіками. Також я не хочу сказати, що ґендерна теорія $є$ істинним джерелом знань про ґендер. Радше я хочу показати, як ця конференція та книжка ілюструють розрив між знаннями і практиками спільнот та академічними дискурсами. На мою думку, корисно і важливо помістити обговорення жіночих та лесбійських маскулінностей в опозицію до узагальненої дискусії щодо маскулінності у студіях культури, де маскулінність вперто вважають властивістю тільки чоловічих тіл. Постійна відмова західних суспільств залучити ґендерноамбівалентні тіла в функціональну соціальну взаємодію (доказом чому є, наприклад, існування тільки або/або туалетів, себто поділ на чо-

\footnotetext{
${ }^{15}$ Нині зростає кількість журналів, що мають спеціальні числа, присвячені маскулінностям, проте в жодному я не знайшов хоча б одного есею на тему жіночої маскулінності. Допіру мені трапився анонс нового числа журналу «The Velvet Light Trap: A Critical Journal of Film and Television», присвяченого «новим маскулінностям» (1996). Зміст рясніє заголовками на зразок: «Нова маскулінність у “Тутсі”» («New Masculinity in Tootsie»), «Про батьків та синів, секс та смерть» («On Fathers and Sons, Sex and Death»), «Чоловіча мелодрама та чутливі чоловіки» («Male Melodrama and the Feeling Man») тощо. Не те, щоб ці статті були нецікавими, проте «нові маскулінності» підозріло схожі на старі.
} 
ловічі і жіночі) є, як я покажу далі, результатом консервативного та протекціоністського ставлення чоловіків до маскулінності. Таке ставлення підтримується загальним невизнанням жіночої маскулінності. Але це невизнання можна вважати хіба що результатом провалів у колективній уяві, адже вже понад сотню років люди, що народжені як жінки, наполегливо і переконливо підважують когерентність чоловічої маскулінності; що ж перешкоджає цим спробам досягти цілі й послабити зв'язок між маскулінністю та чоловіками? Чомусь дотепер не існує загального визнання або бодай прийняття маскулінних жінок та хлопчакуватих дівчат, хоч ми знаємо численні приклади сильних жінок як бодібілдерка Бев Френсис чи тенісистка Мартіна Навратілова (Bev Francis, Martina Navratilova), крос-ідентифікованих жінок Редкліф Гол чи Етель Сміт (Radclyffe Hall, Ethel Smyth), маскулінно репрезентованих громадських діячок - Дженет Ріно (Janet Reno), зіркових бучів - кей ді ланг (k.d. lang), м'язистих і атлетичних жінок - Джекі Джойнер-Керсі (Jackie JoynerKersee), народжених як жінки трансгендерних людей - Леслі Файнберг (Leslie Feinberg). Мою книжку присвячено вивченню цих колективних невдач помислити та утвердити маскулінність, створену жінками, для жінок і серед жінок.

Якщо раптом моє занепокоєння сучасними дискусіями довкола маскулінності у студіях культури звучить надто знецінливо, пропоную докладніше розглянути, що відбувається, коли академічні дискусії про чоловічу маскулінність здійснюються шляхом вилучення дискусій щодо ширшого діапазону маскулінностей. Може видатися, ніби я непропорційно багато уваги зосереджую на одній книжці, яка, зрештою, є лише осібним випадком, та в ній віддзеркалено типові наміри й помилки ширшого кола досліджень маскулінності. У збірці «Хлопці: маскулінності в сучасній культурі» із серії «Студії культури», упорядник Пол Сміт стверджує, що про маскулінність завжди слід мислити «у множині», бо маскулінності «визначено і сформовано цілою низкою відмінностей та суперечностей» (Smith 1996, 3). Для Сміта множинні маскулінності включають домінантну білу маскулінність і відмінні від неї гей, бісексуальні, чорні, азійські та латино маскулінності. I попри визнання множинних маскулінностей, Сміт вирішує зупинитися саме на домінантній білій маскулінності коштом вилучення інших перелічених ним. I я вже не здивований, коли Сміт застерігає читацтво не потрапити в пастку спокуси просто критикувати домінантну маскулінність чи просто підтримувати міноритарні маскулінності, а далі робить таку засадничу заяву:

«I може навіть, як стверджують деякі впливові голоси, маскулінність чи маскулінності посутньо не є "власністю" винятково біологічних чоловічих суб'єктів, адже чимало жіночих суб’єктів претендують на маскулінність як свою "вотчину". Та все ж, у сенсі культурної та політичної влади, це досі стратегічно важливо вивчати маскулінність, суміщену із чоловічим тілом» (Smith 1996, 4-5). 
Що впало мені у вічі - це дивне приписування непомірної сили отим «впливовим голосам», які напосідливо повторюють, що маскулінність не $\epsilon$ власністю чоловіків. Ці впливові голоси не поіменовано, і можна припустити, що це настільки знані «теоретикині і теоретики жіночої маскулінності», що називати їх зайве. Далі Сміт просить читацтво погодитися, що поєднання чоловічої статі та маскулінності і «досі» ще стратегічно важливе. Його апеляція до здорового глузду створює враження, буцім він повертає в раціональне русло дискусію, що збилася на манівці. Але насправді Сміт просто каже, що треба розглядати домінантну маскулінність, щоб деконструювати маскулінність, адже тільки додавання чоловічої статі і маскулінність у сумі дають соціальну легітимність. Але, як я писав вище в цьому розділі, саме тому, що біла чоловіча маскулінність відтіснила всі інші маскулінності, треба відійти від ії виявів, і тоді з'явиться можливість побачити інші, мобільніші форми маскулінностей. Коли Сміт перезапевняє нас, мовляв вивчення чоловічої маскулінності стратегічно важливе, він прагне вказати на «культурну і політичну владу» цього союзу, аби скерувати нашу увагу на владу патріархату. Про це чітко йдеться в другій частині цитати:

\begin{abstract}
«Врешті-решт, біологічні чоловіки - особи чоловічої статі - $є$ носіями, хоч і різною мірою, привілеїв та влади в системі, проти якої продовжують боротися жінки. Ці привілеї та влада, звичайно, по-різному доступні чоловікам, які відрізняються за ознаками класу, етнічності, раси, сексуальності тощо. Але не погоджуся визнати, що існують чоловіки, які не посідають жодної влади та привілеїв у стосунку до жінок. 3 цього огляду, корисно пам'ятати, що маскулінності не $\epsilon$ тільки ефектом домінантних ідей маскулінності й не постають винятково у формі "інших" маскулінностей як ефект ідей спротиву. Насправді маскулінності перебувають у неуникному зв'язку з тим, що фемінізм означив як систему патріархату і патріархальних взаємин» (Smith 1996, 4-5).
\end{abstract}

Характерною ознакою цієї цитати є дивовижна стабільність категорій «жінки» та «чоловіки». Сміт просуває тут дещо застарілу версію фемінізму, яка розглядає жінок як постійних жертв системи чоловічого домінування. Жінка в цій системі - це назва для таких суб’єктів патріархату, що не мають доступу до чоловічої влади і яких регульовано та обмежено патріархальними структурами. Але що Сміт відповів би Монік Вітіг, яка зазначає, що лесбійки - це не жінки, оскільки вони не $є$ частиною гетеросексуальної матриці, що продукує статеві відмінності як владні стосунки (Wittig 1992)? Що б він сказав на впливову теорію «ґендерного неспокою» Джудит Батлер, згідно з якою «ґендер є копією без оригіналу», а домінантні сексуальності та ґендери в якомусь сенсі постійно залежні від своїх інших і відчувають постійну від них загроженість (Butler 1991)? Що сказав би Сміт на заувагу Джейкоба Гейла, що гендери, до яких апелює ґендерна теорія, дуже відмінні від альтернативних гендерів, продукованих спільнотами (Hale 1996)? Чи є буч-ле- 
сбійки жінками? Чи є трансвестити ${ }^{16}$ чоловіками? Як ґендерна некомформність перериває плин влад, облаштованих патріархатом у стосунках між чоловіками та жінками? Іншими словами, Сміт не може взяти до уваги жіночої маскулінності, бо в його очах вона виглядає незначущою, вторинною, у порівнянні із значно важливішим питанням чоловічих привілеїв. Але тоді це знову виглядає радше як нудне повторювання, що чоловіки таки досі посідають чоловічу владу в патріархальній системі (хіба ні?), і дає змогу зручно не помічати, що гендерні взаємини дають збій, коли в гру вступають ґендерноваріативні тіла.

Принцип посилювати чоловічу маскулінність, применшуючи вагу інших маскулінностей, Сміт застосовує і в іншому місці, коли робить спробу проаналізувати расовані маскулінності. Вступний есей він розпочинає розглядом складної справи О. Джея Сімпсона ${ }^{17}$ і дивується, чому обговорення цього судового процесу здебільшого точиться навколо теми раси, а не маскулінності та чоловічого домінування. Почувши, як один чорний чоловік, слухач радіошоу, у прямому ефірі по телефону сказав, що справа О. Джея є частиною змови проти чорних чоловіків у США, Сміт прокоментував це так: «Його теревені про спроби геноциду чорних чоловіків нагадали мені чомусь ще одну особливість справи 0. Джея: усе почалося із судової справи, яка мала з'ясувати, чи достовірними є обвинувачення О. Джея у побитті дружини» (Smith 1996, 1). Думка, що людям, які телефонують на ток-шоу, нічого сказати про цей аспект справи, наштовхує Сміта на запитання: чи здатна раса сформувати колективну ідентичність, тоді як маскулінність - не здатна, і зрештою він доходить висновку: «Хоч, ймовірно, важко говорити в цій країні про расу, але говорити про маскулінність ще важче» (Smith 1996, 1). Коли ти білий чоловік, це, мабуть, і справді важко говорити поокремо про расу або про маскулінність, а водночас, то й поготів. Але, певна річ, расу і маскулінність, особливо у випадку О. Джея, неможливо розділити на чисті категорії. І з цілковитою певністю можна сказати, що «теревені» додзвонювача про змову проти чорних чоловіків були змістовнішою спробою расового аналізу справи, аніж Смітів розбір зв’язку між маску-

\footnotetext{
16 Тут і надалі автор паралельно вживає і застарілий нині, паталогізуючий термін «трансвестит», і нейтральніший (з огляду на сучасні мовні політики) - «крос-дресер». У перекладі ми в усіх випадках зберігаємо (калькуємо) слововжиток Галберстам, що віддзеркалює мовну ситуацію США другої половини 1990-х років. - Прим. пер.

${ }_{17}^{17}$ О. Джей Сімпсон (O. J. Simpson, 1947) - американський футболіст, «відомим» став у зв'язку зі звинуваченням у вбивстві дружини Ніколь Сімпсон та її коханця. Одним із аргументів захисту було твердження, що справу сфальсифікувала поліція через расистські упередження. Опісля довгих судових процесів, у 1995 році журі присяжних виправдало Сімпсона. Таке рішення суду було безпрецедентним, адже справи, де чорного чоловіка звинувачено у злочині проти білої жінки здебільшого через расистські упередження, закінчувалися звинувальним вироком. Однак у 1997 році в рамках громадського судового процесу його визнали винним, суд зобов'язав Сімпсона виплатити компенсації родинам загиблих. - Прим. пер.
} 
лінністю та расою. Для Сміта маскулінність у випадку О. Джея є умовою домінування, яка вступає в суперечність із його «чорністю» як умовою субординації. Тут не йдеться ані про несправедливість правової системи, ані про роль класу та грошей у судовому процесі, ані про складну історію взаємин між чорними чоловіками та білими жінками. Сміт використовує О. Джея тільки задля прикладу, коли влада та безвладність перебувають в одному місці.

Я присвячую так багато уваги аналізу вступного есею Сміта в збірці «Хлопці...», бо цей есей ілюструє типову байдужість до проекту вивчення альтернативних маскулінностей і засвідчує небажання брати до уваги заплутані складники, що формують сучасні владні режими на перетині ґендеру, раси та класу. Та й сама книжка, розпочата есеєм Сміта, також нічого нового не додає до дискусій про маскулінність, натомість, починаючи від вступу і далі, ми швидко впізнаємо знайому територію чоловіків, хлопчиків та їхніх татів. Скажімо, уже перший есей «Баффало, Нью-Йоркська історія» Фреда Файла є сумною оповіддю про стосунки батька та сина у 1950-х. В одному пам'ятному фрагменті спогадів Фред і його тато, вмостившись на дивані, дивилися «Бонанцу» ${ }^{18}$, доки мама та «сеструха» готували їжу на кухні. Хлопчик питає в батька: «Чому погані хлопці завжди такі дурні?» Сміючись, тато відповідає: «Тому що вони погані» (Pfiel 1996, 10). Далі в історії йдеться про те, як уперше невинний хлопець зіштовхується з расизмом своїх родичів-чоловіків, а також про його важку боротьбу з хитавицею. Окрім розбору динаміки затишної сцени з переглядом «Бонанци» на дивані, існує ще чимало інших важливих речей про чоловіка та маскулінність у патріархаті, але Сміт та деякі автори збірки їх ігнорують. Можна було здійснити етнографічне дослідження агресивних, реально протофашистських маскулінностей, створених спортивними фанатами ${ }^{19}$. Усе ще мало досліджено соціалізацію юнаків у старшій школі (або відсутність соціалізації), домашніх насильників (зокрема білих і заможних), новий сексизм від «чутливих чоловіків», чоловіків, що залучені в незаконну торгівлю дружинами-на-замовлення та в секс-туризм (разом із дослідженням привілейованої білої гей-маскулінності). Проте дослідження маскулінності не зацікавлені розщепити патріархальний зв'язок між білим чоловіком та привілеєм; ці дослідження значно більше перейняті вразливістю чоловічої соціалізації, муками чоловічої зрілості та страхом перед здобутою жінками владою ${ }^{20}$.

\footnotetext{
${ }^{18}$ Бонанца (Bonanza) - американський телесеріал-вестерн, який транслювали з 1959 до 1973 року. - Прим. пер.

${ }_{19}$ Утім, одне таке дослідження вже $є$, його присвячено вивченню англійських футбольних фанатів, і було б добре зробити щось подібне про американських уболівальників (Buford 1992).

${ }^{20}$ Аби переконатися, що такі теми викликають зацікавлення, загляньте до «чоловічих відділів» ваших місцевих книгарень, а також див.: (Kimmel 1996; Seidler 1994).
} 
Позаяк я тут критикую Сміта за його недостатній внесок у проект виробництва альтернативних маскулінностей, хочу сказати кілька слів про мій внесок у цю справу. Хоч моя маскулінність постає темою останнього розділу в цій книжці, але вважаю за необхідне вказати, що ця книжка $є$ спробою зробити мою жіночу маскулінність справжньою, надійною та реальною. Більшу частину життя мене стигматизували за ознакою маскулінності, вона робила мене незрозумілим і нерозбірливим. Як і решту пацанок, усе дитинство мене сприймали за хлопчика i, подібно до інших пацанок-підліток, мене примушували відповідати стандартам підліткової фемінності. Коли ґендерноамбівалентних дітей безперестанку плутають на основі гендерної ідентичності, ці хибні зчитування можуть створити нову розпізнаваність: іншими словами, постійне плутання пацанок із хлопцями спричиняється до того, що пацанки, зрештою, розвивають маскулінну ідентичність. Лише у двадцять із гаком я врешті знайшов влучне слово для моєї гендерної конфігурації буч. І в останньому розділі «Розлючений булл дайк» я розкажу, як бучі дають раду із завданням ствердити свою маскулінність, яку оточення часто не визнає, заперечує, якій загрожує і над якою чинить насилля.

\section{Туалетна проблема}

Якщо три десятиліття феміністичних теоретизувань про гендер повністю спростували твердження, мовляв анатомія - це доля, гендер природний, а «чоловік» та «жінка» - єдині можливі опції, то чому ми й досі живемо у світі, де існує переконання, буцім люди, які не є чоловіками, - жінки, а люди, які не є жінками, - чоловіки (і навіть, що люди, які не чоловіки, - не люди!) Іншими словами, якщо ґендер уже було цілком очуднено, чому досі нема множинних гендерних опцій, множинних гендерних категорій та реальних нечоловічих і нежіночих варіантів втілень? Якоюсь мірою саме ця мінливість і розмитість ґендеру уможливлює панування гендерного диморфізму. Або скажу інакше, саме тому, що лиш мала частка людей відповідає культурним стандартам чоловічості та жіночості, ґендер може бути неточним, а відтак, може по-різному передаватися в межах непорушної бінарної системи. I водночас, саме тому, що грань між чоловічістю та жіночістю $є$ такою еластичною, зовсім мало людей у будь-якому публічному місці залишатимуться цілковито гендернонезчитуваними.

Амбівалентний ґендер - де і за яких обставин він не з'являвся б неодмінно інтерпретуватимуть як девіацію, третість чи нечітку версію або чоловіка, або жінки. Скажімо, багато відвідувачок громадських вбиралень не відповідають установленим стандартам фемінності, але тільки ті з нас, хто виглядають дещо амбівалентно, безперестанку наштовхуються на звинувачення, що вибрали «не ту» вбиральню. От нещодавно, прямуючи у справах до Міннеаполіса, я чекав на пересадку в чиказькому аеропорту О’Гара. Я цілеспрямовано рушив до жіночого туалету. 
Щойно за мною зачинилися двері, пролунало: «Відчиніть, це охорона!» Я розумів, що відбувається. Мене знову сприйняли за чоловіка чи хлопця, і якась пані викликала охорону. Почувши мій голос, двоє охоронців зрозуміли свою помилку, пробелькотіли вибачення та зникли. Дорогою додому, у Денверському аеропорту, трапилося те саме. Так, у просторі аеропорту, де люди подорожують буквально крізь час та простір, і перетин одних кордонів (національних) викликає бажання стабілізувати інші кордони (ґендеру), контроль ґендеру в туалетах посилений. Утім, багато андрогінних чи маскулінних жінок потрапляють під підозру й у всіх інших жіночих туалетах; це трапляється так часто, що виникає думка, чи не $є$ категорія «жінка» застарілою, коли йдеться про громадські вбиральні? ${ }^{21}$

Те, що транспортні вузли стали зонами пильного нагляду та ревізії, не $\epsilon$ випадковістю. Але ґендерний контроль у туалетах аеропортів $\epsilon$ лише посиленою версією ширшої «туалетної проблеми». Деяким ґендерноамбівалентним жінкам відносно легко «довести» своє право на жіночу вбиральню - вони можуть засвідчити видимі ознаки свого ґендеру (високий голос, груди), тоді всі питання розвіюються. Іншим особам - із низьким голосом, пласкими грудьми чи волоссям на тілі/обличчі - доволі важко виправдати свою присутність у жіночому туалеті, тому вони можуть скористатися чоловічим туалетом, нагляд за якими менш пильний. Так-от, у цих туалетних протистояннях ґендерноамбівалентна особа спочатку розпізнається як не-жінка («Ви помилилися вбиральнею!»), але потім ця особа постає як щось ще жаскіше - не-чоловік («Аж ніяк ні!!» - сказане голосом, що розпізнається як нечоловічий). Отож, ґендерноамбівалентна відвідувачка вбиральні вважається не-чоловіком i не-жінкою, але також не вважається андрогінною чи проміжною [inbetween] особою, ні, вона постає як гендерна девіантка.

Для багатьох ґендернодевіантних осіб ідея пасу ${ }^{22}$ принципово не помічна. Наратив «пасабельності» передбачає, що існує певна самість, замаскована під іншу самість, і це в неї добре виходить; у певний мо-

21 У сучасних дослідженнях актуальність категорії «жінка» все частіше береться під сумнів. Монік Вітіг в есеї «Пряме мислення» стверджує, що «лесбійки - не жінки» (Wittig 1990: 21) [тут також гра слів: англійське straight - а саме це англійське слово використовує Вітіґ у заголовку французькою мовою - означає прямий і водночас $€$ сленговою назвою гетеросексуальності. - Прим. пер.]. Позаяк лесбійки відкидають стосунки із чоловіками, вони не можуть займати позицію «жінок», каже Вітіг. По-філософськи підважити категорію «жінка» спробував і філософ-трансґендер Джейкоб Гейл. Використовуючи радикальне твердження Вітіґ, Гейл теоретизував можливість гендерного втілення, що не вписане в рамку чоловічого та жіночого (Hale 1996). A приміром, Чешир Калгун вважає, що категорія «жінка» може виконувати функцію «комірчини для лесбійок» (Calhoun 1995).

${ }^{22}$ Мати пас, пасабельний (від анг. to pass - проходити) - часто вживане на пострадянському просторі серед транс*/квір-спільнот поняття, що означає мати/відтворювати очікувану зовнішність, стиль одягу, манери тощо, відповідно до обраного бінарного ґендеру, у якому бажають бути, соціалізуватися і/або не привертати зайвої уваги. - Прим. пер. 
мент успішний «пас» формується в щось на кшталт ідентичності. У цей момент особа «з пасом» nостає [has become]. Проте як бути біологічній жінці, яка презентує себе як буч: вона має чоловічий «пас» за одних обставин і зчитувана як буч - за інших, вважає себе не жінкою, проте дистанціюється від категорії «чоловік»? Ідентичність такого суб'єкта найкраще описати як процес із багатьма вузлами становлення і буття. Щоб зрозуміти цей процес, недостатньо лише картографувати психічні та фізичні характеристики на лінії між чоловічим та жіночим в обширі квірного і нормативного простору; ми маємо мислити в категоріях фрактальності та ґендерної геометрії. Окрім цього, у розділі 4, де в обговоренні стоун буч ${ }^{23}$ йтиметься про важливість сексуальності для певних дефініцій гендеру, ми побачимо, як по-різному можуть поєднуватися сексуальність, ґендер та тіло. Стоун буч з її самоозначенням нефемінної жінки, що уникає сексуальних доторків, заперечує ідею, що лесбійки мають однакові жіночі сексуальні практики, що жінки мають однакові жіночі сексуальні бажання чи навіть що маскулінні жінки мають спільне розуміння, що саме формує їхні маскулінності.

Та я хочу більше зупинитись на тому, що називаю «туалетною проблемою», бо мені видається, що вона вияскравлює, як успішно процвітає ґендерна бінарність, хоч і ширяться чутки про її відступ. До того ж більшість нормативно гендерованих жінок навіть не чули про туалетну проблему, вони запевняють, що не знали про труднощі та поневіряння жінок-бучів, яким потрібно скористатися громадським туалетом. А от у квір-літературі доста згадок про туалетну проблему, і без перебільшення скажу, ця проблема $є$ стандартною складовою буч-наративу. Погляньмо, як Леслі Файнберг у романі «Стоун Буч Блюз» описує масштаби туалетної проблеми. У цій історії Джес Голдберг, робітни_ця/к на фабриці [he-she factory worker], описує численні ситуації, коли доводилось приймати складне рішення, як скористатися жіночим туалетом. Під час прогулянки магазинами в товаристві кількох дрег-квінок ${ }^{24}$, Джес каже Пічес: «Мені потрібно в туалет. Господи, потерпіти б, але не можу». Глибоко вдихнувши, Джес заходить до «дамської кімнати»:

Двоє жінок чепуряться перед дзеркалом. Перезирнувшись із подругою, одна дофарбовує губи. «А ось це чоловік чи жінка?» - сказала вона своїй подрузі, коли я проходила повз. Інша повернулася до мене і промовила: «Це жіночий туалет».

Я кивнула: «Знаю». Я закрила за собою двері кабінки. Їхній сміх вразив мене в саме серце. «Ти ж не знаєш насправді, чи це чоловік, чи ні, - сказала одна другій. - Треба викликати охорону, нехай перевірять». Я змила воду і перелякано вовтузилася із застібкою.

${ }^{23}$ Стоун буч (англ. stone butch) - на жаргоні гіпермаскулінна буч-лесбійка. - Прим. пер.

${ }^{24}$ Дрег-квін (англ. drag queen) - сленгове поняття на позначення артистів, які перформують жіночність, використовуючи жіночий одяг, яскравий макіяж, перебільшено фемінну поведінку тощо, щоб створити яскравий сценічний образ. - Прим. пер. 
Можливо, це була жартівлива погроза. А може, вони справді збиралися покликати охорону. Я вибігла із вбиральні, щойно почула, як ці жінки вийшли (Feinberg 1993, 59).

Вбиральня є прикладом обмежень, які спіткають Джес у публічному просторі. Тіло Джес, з його фізіологічними потребами та процесами, стає перешкодою спробам функціонувати нормально і не зважати на гендерноваріативну репрезентацію. Та й жінки в туалеті змальовані радже зловтішними, аніж переляканими. Вони радше розважаються, коли піддають сумніву їі право скористатися туалетом і погрожують викликати поліцію. Як зазначила Джес: «Вони ніколи б так не кпили 3 хлопця». Інакше кажучи, якби жінки справді відчували небезпеку, вони б не кепкували із самозванця і точно не сумнівалися, чи варто кликати поліцію. Буденний тон розмови про охорону свідчить про їхнє розуміння, що Джес - жінка, але хочуть провчити її за цю неприйнятну самопрезентацію.

Ще одна хроніка буч-життя «Жбурни це до річки» філіпіно-канадської письменниці Найс Родріґес теж оповідає про випадок у туалеті. У новелі «Щоповні» Родрігес розказує історію про буча на ім'я Ремедіос, що працює кондукторкою автобуса і закохується в колишню черницю Хуліаніту. Ремедіос «мала жилаві руки та широкі плечі» і її «моцність давала змогу приструнчити будь-кого, хто схоче проїхатись зайцем» (Rodriguez 1993, 25-26). Напосідливо фліртуючи з Хуліанітою, Ремедіос переконує її піти разом до кіна. Ремедіос готується до побачення - старанно забинтовує груди поверх сосків: «Вона купила білу сорочку на Дівісорії 25 , спеціально для цього побачення. Тепер їй тривожно, можливо, тканина надто тонка та прозора і Хуліаніта збайдужіє до неї, якщо помітить, як їі соски видибають із-під матерії» (Rodriguez 1993, 33). У її «добре випрасуваних джинсах», з пласкими грудьми і навіть із чоловічим манікюром Ремедіос вирушає на побачення. Проте в прохідці з Хуліанітою навіть такому блискучому бучеві необхідно бути обережною у громадських місцях. Після кіна Хуліаніта похопилася до вбиральні, але Ремедіос чекала на неї ззовні: «Вона дивним чином боялася жіночих туалетів. Вона хотіла б користатися третьою кабінкою, між чоловічою та жіночою, для таких квірів, як вона. Більшість часу вона стримувала сечу, найдовше півдня, доки не знаходила знайомий туалет, де відвідувачки звикли до неї. Сторонні сприймали її непривітно, особливо старші жінки, які пильно зміряли ї̈ поглядом із ніг до голови» (Rodriguez 1993, 40-41).

Іншим разом Ремедіос розповідає, як її вишпурнув із «дамської кімнати» і побив викидайло. Туалетна проблема критично обмежує можливість Ремедіос і Джес функціонувати в публічних просторах, а також наражає їх на фізичне насильство, бо вони порушили основне правило гендеру: бути миттєво зчитуваним. Якось після нападу батько Ремедіос

${ }^{25}$ Дівісорія (Divisoria) - торговельний квартал у Манілі, де багато бутиків, магазинів, торговельних центрів, розкладок із дешевими товарами. - Прим. пер. 
радить їй бути обережнішою, і Родрігес пише: «Вона зрозуміла, що бути обережною - це виляти стегнами та випинати цицьки щоразу, коли заходиш до жіночої кімнати» (Rodriguez 1993, 30).

Якщо взяти парадигму туалету як мірило гендерних презентацій, то можна помітити, наскільки далекою є бінарна ґендерна схема від живого розмаїття ґендерних досвідів. Звинувачення «ви помилилися туалетом» насправді повідомляє дві різні речі. По-перше, воно каже, що ваш ґендер не узгоджений із вашою статтю (ваша помітна маскулінність чи андрогінність не відповідає вашій ймовірно жіночій статі). По-друге, воно стверджує, що роздільні туалети призначені тільки для тих, хто чітко відповідає одній чи іншій категорії (або чоловік, або жінка). Отож, нам потрібні або спільні чи багатогендерні туалети, або потрібно розширити характеристики гендерного визначення. Туалет, яким ми його знаємо, уособлює провальну гендерну доктрину XX століття. Частота, 3 якою гендернодевіантних «жінок» сприймають за чоловіків у громадських туалетах, спонукає думати, що значна кількість фемінних жінок чимало часу та зусиль присвячують тому, аби поліціювати маскулінних жінок. Зовсім по-іншому функціонують чоловічі громадські туалети, простір яких радше ставатиме місцем для сексуального круїзингу ${ }^{26}$, аніж для гендерних репресій. Лі Едельман в есеї про зв'язки між націоналізмом та сексуальністю стверджує, що «інституційна чоловіча кімната $\epsilon$ місцем, де зони публічного та приватного схрещуються, викликаючи особливу психологічну напругу» (Edelman 1994, 158). Чоловіча кімната, іншими словами, $є$ водночас й структурою нагляду, і стимулює бажання, це простір і гомосоціальної взаємодії, і гомоеротичної взаємодії.

Отож, заки чоловічі туалети функціонують як сильно заряджені сексуальні простори, де сексуальну взаємодію водночас заохочують і карають, жіночі туалети діють як простори для нав'язування ґендерної конформності. Гендерносегреговані туалети продовжують бути необхідними для захисту жінок від чоловічих хижацьких зазіхань, але вони також створюють і поширюють радше застарілу ідею поділу на публічне та приватне між чоловічими та жіночими групами. Туалет $\epsilon$ домашнім простором поза домом, в якому встановлено (або пародійовано) домашній порядок в зовнішньому світі. Жіночий туалет, отже, стає заповідником чіткої фемінності, «кімнатою маленьких дівчаток» ${ }^{27}$, куди усамітнюються, аби напудрити носика та поправити зачіску. А чоловічий туалет $\epsilon$ продовженням публічної суті маскулінності, це виразно не домашній простір, хоч деякі назви, що вказують на сексуальну функцію вбиральні - як «котедж» або «чайна кімната» - й пародіюють домаш-

\footnotetext{
${ }^{26}$ Круїзинг (або крузинг, від анг. cruising) - на гей-жаргоні означає пошук одноразового та анонімного сексу в громадських місцях, на пострадянському просторі відомих як «плєшки» - у громадських убиральнях, парках, на пляжах і тощо. - Прим. пер.

${ }^{27}$ Кімната маленьких дівчаток (англ. little girls room) - евфемізм в англійській мові на позначення жіночого туалету. - Прим. пер.
} 
ність. Коди, які превалюють у жіночих туалетах, насамперед $є$ гендерними кодами; у чоловічих кімнатах - це коди сексуальні. Публічний секс проти приватного гендеру, відкрито сексуальне проти неявно репресивного - громадські туалети виконують роль також і ґендерної фабрики.

Марджорі Гарбер у своїй книжці «Визнане право» у розділі, присвяченому небезпекам та привілеям крос-дресингу, коментує лімінальну роль туалету. Вона розмірковує над різними формами «пасу» та кросідентифікованих генетичних чоловіків та жінок і зауважує, що туалети $\epsilon$ «потенційним Ватерлоо» ${ }^{28}$ як для FtM крос-дресерів і транссексуалів, так і для MtF крос-дресерок і транссексуалок. Для FtM-ів чоловіча вбиральня є найсуворішим випробовуванням їхньої «пасабельності», i y FtM-спільнотах активно циркулюють поради, як бути невикритими в чоловічих середовищах. Гарбер зауважує: «Культурна параноя бути впійманими в абсолютно неприпустимому місці, яка може бути невіддільною від задоволення «мати пас» у цьому ж місці, принаймні частково оперта на той самий культурний бінаризм, ідею, що ґендерні категорії є доволі елементарними, що досить просто співвіднестися з однією із двох «кімнат» без деконструктивного погляду на проблему» (Garber $1992,47)$. Тут варто звернути увагу (хоча б тому, що Гарбер цього не робить), що покара для пасабельних FtM-ів у чоловічих туалетах значно відрізняється від покари пасабельних MtF-iв - у жіночих. 3 одного боку, до FtM-ів у чоловічому туалеті менше придивлятимуться, оскільки чоловіки з об'єктивних причин не такі пильні в туалетах, як жінки. Проте з іншого боку, якщо FtM-а раптом викриють, це може викликати сплеск ґендерної паніки у викривальника і швидко перерости в насильство. У порівнянні з цим, особу MtF можуть уважніше вивчати в жіночому туалеті, але ризик насилля у випадку викриття є значно меншим. Оскільки для FtM-ів на чоловічій території існує постійна потенційна загроза насилля, вкрай важливо зрозуміти, що туалетна проблема - це набагато більше, ніж просто глюк у механізмі ґендерної сегрегації, і краще їі описувати, як насильницький примус сучасної ґендерної системи.

Гарберівське відчитання небезпек для FtM-iв та MtF-ок під час навідин до вбиралень опирається на її вступний аналіз того, що Лакан називає «уринальною сегрегацією». Лакан використовував цей концепт, аби описати відношення між ідентичностями та означниками, і в результаті він використовує просту схему з позначників туалету «Чоловіки» та «Жінки», на прикладі яких показує, як у процесі творення статевої від-

\footnotetext{
${ }^{28}$ Використавши термін «Waterloo» [тут гра слів: loo у просторіччі означає туалет. Прим. пер.], Гарбер створює каламбур про ґендерний контроль у вбиральнях. Хоча він звучить влучно і дотепно, але мене непокоїть, як часто часто Гарбер вдається до каламбурів у своєму аналізі. Подібні дотепи впродовж усієї книжки створюють враження, мов зміна ґендеру - то така собі гра; ба більше, ці каламбури тривіалізують процес зміни ідентифікації, яка нерідко є питанням життя та смерті. Це не значить, ніби з ґендеру не можна жартувати й буцім говорити про нього треба лиш серйозно, тут я хочу тільки звернути увагу на питання каламбурів як теоретичного методу.
} 
мінності означник завжди головує над означуваним; простіше кажучи, називання радше створює зміст, аніж відображає його (Lacan 1977). Так, система «уринальної сегрегації» створює функціональність категорій «чоловік» та «жінка». Хоч видається, буцім значки на туалетних дверях означують уже наперед наявні розбіжності, насправді ці позначники створюють упізнаваність у межах цих конструйованих категорій. Гарбер зупиняється на понятті «уринальної сегрегації», бо воно допомагає описати процеси культурного бінаризму в перебігу виробництва гендеру; на думку Гарбер, трансвестити і транссексуали* кидають виклик системі, опираючись буквальному перекладові знаків «Жінки» та «Чоловіки». Гарбер використовує фігуру трансвестита та транссексуала*, щоб показати очевидні тріщини і розриви в бінарній системі гендеру; трансвестит, мов контрабандист, створює простір «третього варіанта», де всі бінарності втрачають стабільність. На жаль, як і за інших спроб подолати бінарність шляхом створення третього терміна, третій простір Гарбер радше стабілізує перші два. У «Чайних кімнатах та симпатії» Лі Едельман також звертається до лаканівського терміна «уринальної сегрегації», але використовує Лаканову діаграму, щоб означити гетеросексуальний неспокій «щодо потенційних письмових виразів гомосексуального бажання і щодо можливості знати ознаки "гомосексуальної відмінності" та розпізнавати іï» (Edelman 1994, 160). Якщо для Гарбер трансвестит $є$ тим, хто вказує на нестабільність маркерів «Чоловіки» та «Жінки», для Едельмана цю роль виконує не пасабельний трансвестит, а пасабельний гомосексуал.

Доволі прикметно, що і Гарбер, і Едельман розглядають тільки чоловічий туалет як місце, де відбуваються усі ці дестабілізаційні перформанси. Проте, на мою думку, якщо зосереджуватись тільки на драмі чоловічих кімнат, складніший театр жіночих туалетів залишиться непоміченим. Гарбер пише про уринальну сегрегацію: «Для трансвеститів та транссексуалів проблема "чоловічої кімнати" справді $\epsilon$ викликом тому, як ми розуміємо культурний бінаризм» (Garber 1992, 14). На прикладі фільмів «Тутсі» («Tootsie», 1982), «Кабаре» («Cabaret», 1972) та відео 3 «Конкурсу травесті-дів» («Female Impersonator Pageant», 1985) вона показує, які небезпеки виникають у зв'язку з уринальною сегрегацією. Приклади Гарбер, втім, $\epsilon$ не надто вдалими ілюстраціями так званої «проблеми чоловічої кімнати», бо, скажімо, принаймні в одній стрічці «Тутсі» - ґендерний контроль здійснюється власне в жіночому туалеті. Також Гарбер хоче нас переконати, ніби саме чоловічий туалет є місцем суворого гендерного контролю, тоді як жіночий є радше сферою ґендерного тиску. Вона зазначає: «Насправді, пісуар з'являється в цілій низці зовсім недавніх фільмів як знак кардинальної "відмінності" (або завченої байдужості)» (Garber 1992, 14). Очевидно, тут Гарбер проводить паралелі з традиційним атрибутуванням гендеру, де пеніс $є$ ознакою «кардинальної відмінності»; але, зупинившись на всім відомих описах ґендерних розбіжностей, Гарбер залишає поза увагою основну відмін- 
ність між гендерним контролем у чоловічих та жіночих туалетах. А саме, що в жіночих туалетах не тільки MtF-ки, але всі ґендерноамбівалентні жінки $є$ предметом прискіпливої оцінки, тоді як у чоловічих туалетах біологічних чоловіків рідко ставлять під сумнів. Коли Гарбер наполягає на «можливості третього простору», призначеного для трансвеститів, вона виключає існування четвертого, п'ятого, шостого чи сотого простору поза бінарністю. «Проблема жіночої кімнати», на противагу до «проблеми чоловічої кімнати», вказує на множинність гендерних дисплеїв навіть у межах на позір стабільної категорії «жінка».

Отож, який ґендер мають сотні людей, що народжені як жінки, які в жіночих туалетах систематично не зчитуються як жінки? I якщо так багато жінок не проходять тест «жіночої кімнати», чому ж ми не починаємо зважати на них та називати ці гендери, які, вочевидь, виникають отепер? На це питання можна відповісти двояко: з одного боку, ми не даємо назв і не помічаємо нових ґендерів, бо ми як суспільство віддані справі підтримки бінарної системи ґендеру; з іншого боку, можна також сказати, що оскільки категорії «чоловік» і «жінка» не охоплюють усе поле ґендерної варіативності, це і забезпечує їхнє тривале домінування. Себто саме тому, що буквально ніхто не відповідає визначенню «чоловік» та «жінка», саме ця неможливість забезпечує цим категоріям владу й обіговість. Іншими словами, гнучкість та еластичність категорій «чоловік» та «жінка» й уможливлює їх постійність. Аби пересвідчитись у цьому, огляньте будь-яке публічне місце і переконайтеся, як мало людей відповідають стереотипному гендерному образу i, водночас, як мало людей $є$ незчитуваними або амбівалентними. Серія скетчів «Це - Пат» («It’s Pat») у шоу «Суботнього вечора, наживо» («Saturday Night Live») унаочнює нестримне бажання людей з'ясувати гендер (чоловічий або жіночий) навіть найневизначеніших осіб. Дійова особа у фільмі «Це Пат» ${ }^{29}$ створює комічні ситуації тим, що постійно ухиляється від визначення власного гендеру, партнер* Пат має нейтральне ім'я, і всі дії та слова Пат можна постійно читати двояко. Звичайно, загадку Пат можна було б легко розгадати, просто запитавши Пат про їх ґендер. 3 позицій мого дослідження про жіночу маскулінність, таких відповідей може бути більше, ніж дві, або навіть можна обстоювати концепцію «гендеру на вибір» як альтернативу примусовому гендерному бінаризму. Уміння людей створювати дуже точні класифікації представлено в багатьох сферах; чому ж тоді ми маємо так гранично мало варіантів, коли йдеться про ґендер? Система ґендеру на вибір могла б запропонувати варіант гендерної нейтральності до моменту, коли дитина чи молода людина змогла б заявити про її, його чи їхній гендер. Навіть якщо ми не можемо скасувати ґендерної бінарної системи, усе ж $є$ можливість зробити ґендер предметом вибору: люди зможуть робити гендерні камінаути, так

29 Pat може бути як скороченням від імені Патрік (Patrick), так і від Патриція (Patricia). - Прим. пер. 
само як роблять камінаути сексуальні. Я веду до того, що $є$ чимало шляхів депатологізувати ґендерну варіативність і підтримати ті різні гендери, що вже створені й існують. І нарешті, як я вже зазначав, коментуючи аргументи Гарбер щодо трансвестизму, третість хіба що лиш урівноважує бінарну систему і, щобільше, схильна радше гомоґенізувати різні ґендерні варіації під шапкою «іншості».

У цьому суспільстві на диво легко виглядати не як жінка. У порівнянні з цим, вкрай важко виглядати не як чоловік: небезпеки, які чигають на ґендернонеконформних чоловіків, дещо відмінні від небезпек щодо жінок. Чоловіки значно рідше мають проблеми з пасом у громадському туалеті, хіба що чоловік свідомо прагне виглядати як жінка. Тож туалетна проблема ставить перед нами ось яке питання: що робить фемінність такою приблизною, а маскулінність такою точною? Або переформулюю, чому фемінність так легко можна імперсонувати та перформувати, тоді як маскулінність, схоже, не допускає наслідування? Звичайно, це питання швидко переростає в протилежне: чому, наприклад, у випадку маскулінної жінки в жіночому туалеті нестача фемінності миттєво стає очевидною, а от брак маскулінності в чоловічому туалеті поняття розпливчасте.

Ми могли б підійти до цих питань через розмірковування про соціальні та культурні ефекти протилежної гендерної типізації. Інакше кажучи, про те, якими є наслідки чоловічої фемінності та жіночої маскулінності. На перший погляд може видатися, що навіть найменший натяк на фемінність заплямовує чи понижує соціальну значущість чоловіка, а от маскулінність жінки мала б, навпаки, підвищувати ії статус ${ }^{30}$. Та навіть мій описаний вище досвід у туалетах показує, що це не так. Водночас, якщо ми згадаємо популярні образи прийнятної жіночої маскулінності, втілені жилавою Ліндою Гамільнот у «Термінаторі 2» («Terminator 2: Judgment Day», 1991) або атлетичною та лютою Сігурні Вівер у «Чужих» («Aliens»), неважко помітити, що саме робить ці образи жіночої маскулінності прийнятними: це їх безумовна гетеросексуальність. Проте коли в «Чужому*: Воскресіння» («Alien: Ressurection») атлетична Ciгурні Вівер злегка фліртує з іншою зіркою Вайноною Райдер, iї маскулінність миттєво стає значно загрозливішою і таки «чужою». Тобто там, де жіноча маскулінність суміщена з можливою квірною ідентичністю, у неї мізерні шанси дістати визнання. Оскільки жіноча маскулінність видається найзагрозливішою, коли вона поєднується з лесбійським бажання, у цій книжці я зосереджусь на квірній жіночій маскулінності, а гетеросексуальну жіночу маскулінність практично не розглядаю. Я не сумніваюся, що гетеросексуальна жіноча маскулінність своїм робом підриває ґендерну конформність, проте дуже часто вона $є$ прийнятнішим варіантом

\footnotetext{
${ }^{30}$ Сьюзен Бордо пише: «Коли ми демонтуємо маскулінність у своїй культурі, така деконструкція перетворює нас на стидобище; коли ж ми символічно деконструюємо фемінність, це спричиняється до значного підвищення статусу» (Bordo 1993, 721).
} 
жіночої маскулінності, порівняно з надмірною маскулінністю лесбійки. Розмірковуючи про ґендерні варіації, такі як чоловіча фемінність та жіноча маскулінність, важливо не створювати чергову бінарність, де маскулінність завжди позначає владу; в альтернативних моделях ґендерної варіативності жіноча маскулінність - це не протилежність жіночій фемінності і не жіночий варіант чоловічої маскулінності. Це радше, як буде показано далі на прикладі мистецьких робіт і ґендерного перформансу, нечестивий союз жіночості та маскулінності, що здатен породити геть несподівані ефекти.

\section{Міноритарні маскулінності і ґендерне мистецтво}

Міноритарні маскулінності та фемінності дестабілізують бінарну гендерну систему в різних сферах. Феміністична та антирасистська критика часто вказує на те, що фемінність та маскулінність $€$ нормативними лише в поєднанні з білими гетеросексуальними тілами середнього кла$\mathrm{cy}^{31}$. Отож, стрічки небілих режисерів, що порушують цей репрезентаційний канон - скажімо, «У пошуках Ленг'стона» Айзека Жульєна (Issac Julien «Looking for Langston», 1988) або «Сполучені язики» Марлона Ріґза (Marlon Riggs «Tongues United», 1989), здатні переформувати ієрархізовані відносини між домінантними та міноритарними сексуальностями, але також мають потенціал реорганізувати маскулінність як таку. Поєднання стереотипізації та контрапропріації ми можемо спостерігати на прикладі нового твору масової культури, де в межах скопічного режиму расування [scopic regime of racialization] зображено появу міноритарної маскулінності. У фільмі «Виклик» («Set it Off», 1996) йдеться про чотирьох чорних жінок, які у відповідь на жаску соціальну несправедливість вдаються до злочинної діяльності. Тут реперка Квін Латіфа (Queen Latifah) грає персонажку, яку можна означити як «буч із району».

Латіфина персонажка - Клеопатра Сімс (Клео) - це горлата, задиркувата, сувора злочинниця-буч, яка має милу коханку та хуліганські манери. Чорну жіночу маскулінність Клео зіперто на стереотип про чорних жінок як менш фемінних, у порівнянні з міфічним еталоном білої фемінності, але водночас тут також цілковито змінено значення цього стереотипу. Якщо чорність загалом асоціюється в суспільній уяві 3 надмірною та агресивною маскулінністю, то Латіфа в ролі Клео з певним успіхом використовує цю асоціацію. Щоб довершити образ, Латіфа (яка й сама є реперкою) позичає гіпермаскулінні рухи чорних реперів

\footnotetext{
31 Наприклад, Річард Фанг в есеї про гей-порнографію стверджує, що наративні структури порнографії містять гадку, що глядач* - білий чоловік, який є втіленням чоловічої краси та мірилом чоловічого бажання. 3 цього огляду, порно характеризує чорних чоловіків як гіперсексуальних та загалом фалічних, а азійських чоловіків пасивних, асексуальних (Fung 1991).
} 


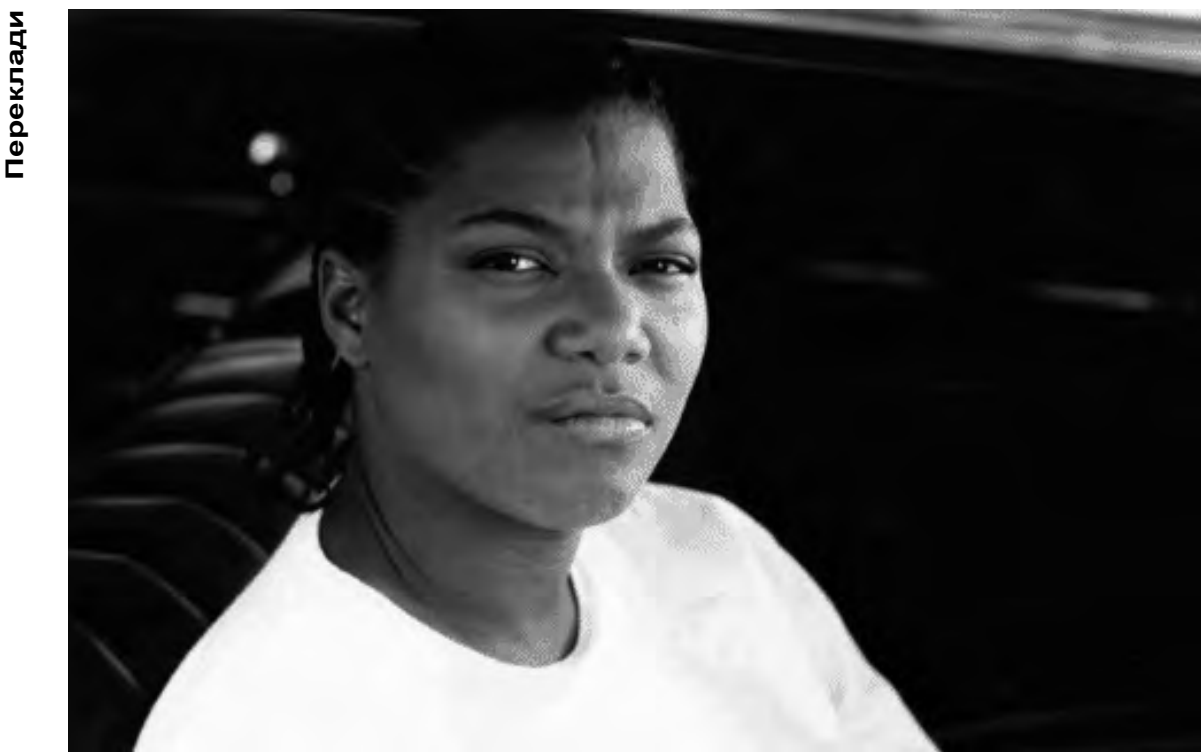

«Буч із району». Квін Латіфа - «Клео» у фільмі Ф. Гері Грея «Виклик» (1997)

і яскраво увиразнює привабливість і небезпечність маскулінного перформансу «пацанів із району» ${ }^{32}$.

Іншим наступом на домінантні гендерні режими $\epsilon$ квірне буч-мистецтво та вистави - дрег-кінг ${ }^{33}$ шоу, театральні ролі бучів або присвячені ґендерноамбівалентним суб'єктам мистецькі проекти. Наприклад, як ми побачимо в розділі 7, зірки на кшталт Елвіса Герселвіса чи Мо Бі Діка (Mo B. Dick) ${ }^{34}$ під час своїх дрег-кінг вистав викривають домінантну маскулінність через пародіювання чоловічої суперзоряності й обігрування у своїх комедійних сценках конвенційних модусів сексизму і мізогінії. Скажімо, дрег-кінг Морін Фішер (Maureen Fisher) в образі Мо Бі Діка вміло пародіює маскулінність через розігрування найбільш штучного і награного їі аспекту - сексизму. Коли Мо Бі Дік сповіщає аудиторії дрег-клубів про свою гетеросексуальність, страх перед «гомиками» чи про хіть до «дівок», це має виразний присмак мізогінних жартів. Його представлення награної, театральної маскулінності привертає увагу

\footnotetext{
32 Про політики видимості стосовно сексуальності чорних жінок йдеться докладніше в есеї Евелін Гаммонс, де авторка зазначає: «Сексуальність чорних жінок... має бути водночас невидимою, видимою (демонстрованою), гіпервидимою та $є$ патологізованою в домінантних дискурсах» (Hammons 1997, 170).

${ }^{33}$ Дрег-кінг (англ. drag king) - сленгове поняття на позначення артисток, які перформують маскулінність, використовуючи чоловічий одяг, наслідують чоловічі манери і зовнішність, щоб створити яскравий сценічний образ. - Прим. пер.

${ }^{34}$ Сценічне ім'я цього дрег-кінга є грою зі смислами: Мо Бі Дік відсилає до роману Мелвіла «Мобі Дік» і водночас може буквально прочитуватися як «Мо Великий Член». Прим. пер.
} 
не лише до перформативного аспекту маскулінності, а й до місць, де неперформативність має ідеологічне підгрунтя. Іншими словами, демонструючи театральність улесливої чоловічої уваги до жінок, мистецтво дрег-кінгу відкидає будь-які інтерпретації мізогінії як природного стану справ.

у дещо іншій формі буч-театру, у квірній виставі Пегі Шоу «Ти геть як мій батько» (Peggy Shaw «You're Just Like My Father», 1995), сама Шоу представляє жіночу маскулінність у викличній і безкомпромісній театральній постановці про зміну родинної динаміки завдяки доньці-бучу. Маскулінність Шоу, без сумніву, є частиною іï лесбійськості, а не дрег-

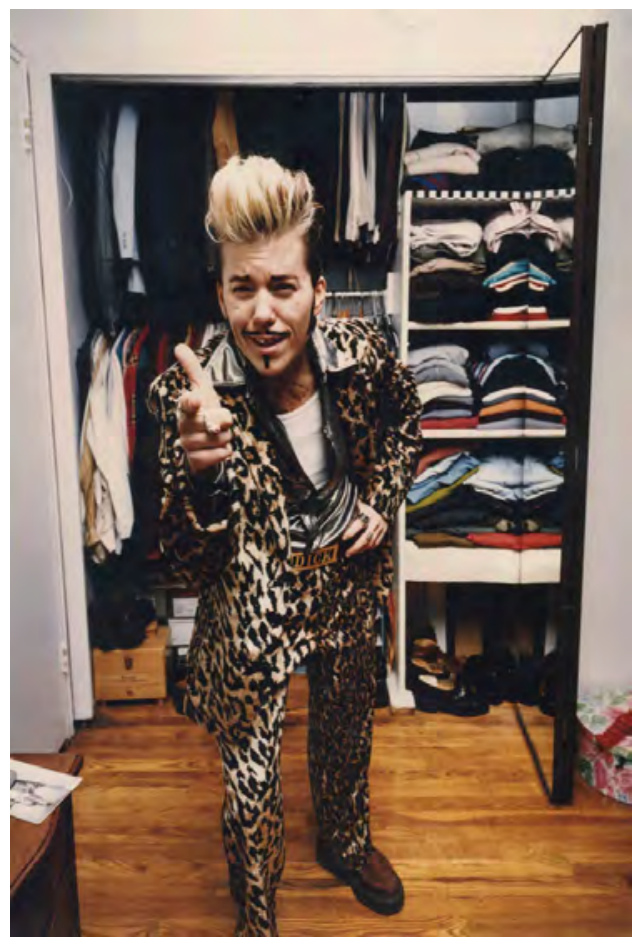

«Вийти із шафи». Дрег-кінг Мо Б. Дік, фото Дела Грейса (Нью-Йорк, 1997) ідентичністю і не імітуванням чоловічості. Шоу є субститутом чоловіка для своєї матері, і заміняє батьків та братів для своїх коханок, вона конструює та удосконалює свою маскулінність за допомогою маскулінностей, які може спостерігати довкола. Вона легко змінює іпостасі: вона боксер, крунер ${ }^{35}$, солдат, годувальник, ромео, патріарх. У всіх цих ролях Шоу чітко показує, що вона є людиною з жіночим тілом, в якій живе кожна з цих ролей, і кожна ця роль $є$ частиною її гендерної ідентичності. Ба більше, щоб зіграти всі ці різні маскулінні персонажі, Шоу не вимушена стати своїм батьком або привласнити його маскулінність: вона вже $\epsilon$ «геть як» її батько, їхні маскулінності існують на різних поверхнях.

Жіноча маскулінність з'являється не лише в кінострічках чи театральних виставах. У фотомистецьких доробках Кетрін Опі та Дела Грей$\mathrm{ca}^{36}$ (Del Grace) ми також можемо спостерігати, як захопливо і переконливо жіноче тіло стає маскулінним. У створених Кетрін Опі соковитих портретах учасниць лесбійських, трансгендерних, SM-спільнот зображено особливий тип жіночої маскулінності. Один із ії ранніх проектів під

\footnotetext{
${ }^{35}$ Крунер - співак, що послуговується вокальною технікою свінгування. - Прим. пер. ${ }^{36}$ Дел Лагрейс Вулкано (Del Lagrace Volcano) $\epsilon$ гендерноваріативною особою. В оригіналі Галберстам пише про Дел Грейса в жіночому гендері, проте нині Дел використовує займенники чоловічого роду, тому в перекладі цього тексту Грейс згадується в чоловічому роді. - Прим. пер.
} 


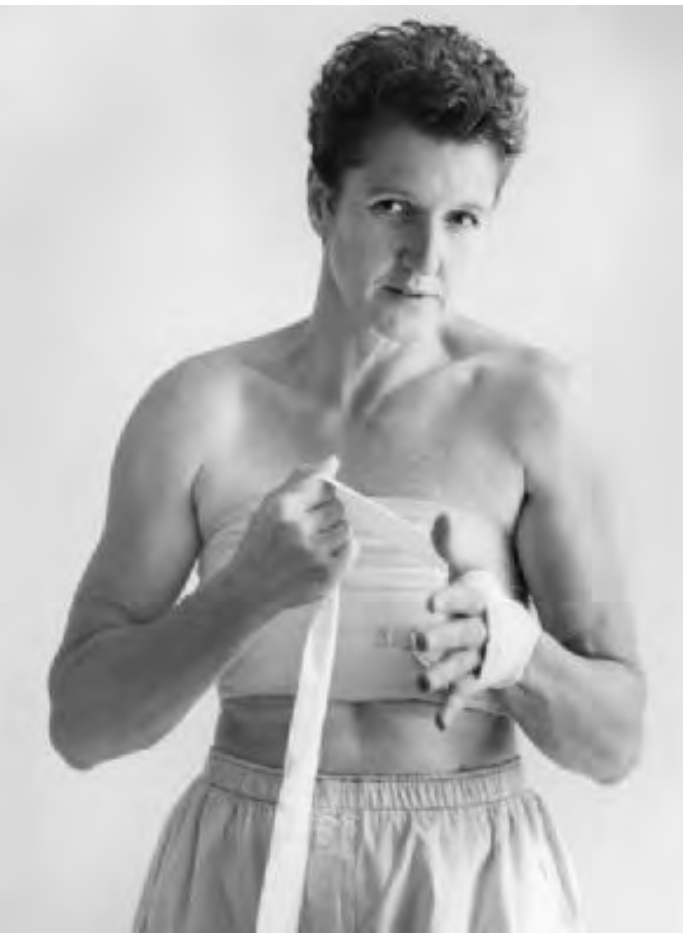

Пегі Шоу в образі для вистави «Ти геть як мій батько», фото Еви Вайс (1993) назвою «Бути та мати» («Being an Having», 1991) $\epsilon$ серією портретів вусатих та бородатих облич, зображених на інтенсивно-жовтому тлі. На кожній світлині камера наближає обличчя моделі впритул, аж обрізає маківку, і аудиторія опиняється лицем до лиця, яке водночас залишається химерно незчитуваним. Оті великі наближення створюють відчуття на кшталт інтиму між моделлю й мисткинею, який заразом досяжний для глядацтва. Особа, яка споглядає фотографію, позиціонується водночас і як вуаєристка, і як дзеркальний образ, і як учасниця, але сама ця особа відчуває себе буцім схо-

пленою між цими двома поглядами, між бути і мати.

Часто камера бере доволі великий план, аж видно, що рослинність на обличчі $є$ бутафорною; але на деяких обличчях рослинність справжня, і це стає візуальною пасткою, бо авдиторія відразу ж прагне з'ясувати, чиє це обличчя - чоловіче чи жіноче. Це $є$ пасткою, бо роботи Опі зовсім не про бінарність ґендеру, кожен наступний портрет привносить новий вимір гендеру, не обмежуваний категоріями «чоловік» або «жінка». Щоправда, чимало коментарів до робіт Опі кажуть, що комплексність цих робіт полягає в тих «ледь усвідомлюваних процесах, що запускаються, коли ми намагаємося з'ясувати, хто перед нами - чоловік чи жінка» (Pagel 1994, 45). Поза тим, якщо глянути на роботи Опі в ширшому контексті виробництва жіночої маскулінності, то амбівалентність ґендеру - не те, про що в них ідеться. Ці портрети не амбівалентні, це однозначні образи жіночої маскулінності, яку, каже Опі, її крос-дресерки втілюють «як у ліжку, так і у публічних просторах. Вони, я гадаю, $\epsilon$ ексгібіціоністками, а їхня сцена стає публічним видовищним спортом» (Smith 1991, 83) ${ }^{37}$.

37 «Жіночий погляд...» - чудова рання рецензія на творчість Кетрін Опі, проте така назва вказує, ніби фемінність притаманна всьому, що продукують жінки (Smith 1991). Але ж у роботах Опі немає нічого фемінного. 
За допомогою світлин бородатих, татуйованих, пірсингованих маскулінних лесбійок і трансгендерних чоловіків Кетрін Опі створює потужну візуальну естетику альтернативних та міноритарних маскулінностей. Ї̈̈ роботи порівнюють із творчістю Діани Арбус (Diane Arbus), бо та фотографувала так званих виродків* та фріків*. Опі категорично відкидає це порівняння. Вона каже: «Я стараюся зобразити людей із надзвичайною гідністю. Тобто, певна річ, на них все одно витріщаються, але я намагаюся зробити так, щоб портрети витріщалися у відповідь. Це все про взаємини. Це не схоже на Діану Арбус чи якісь інші подібні роботи. На деяких портретах люди виглядають сумними, може, дещо відчуженими, але ніколи не жалюгідними» (Opie 1996, 29). Твердження Опі, що їі портрети «витріщаються у відповідь», створює цікаву владну динаміку не тільки між фотографкою та моделлю, а також між зображенням та авдиторією. Владний погляд у роботах Опі завжди властивий зображеним: невідривний погляд змушує глядацтво завагатися у власному розумінні гендерної відповідності, та навіть і в розумінні себе, і це схоже на неприязні витрішки, - досвід, який моделі ймовірно переживають чи не щодня. Один рецензент писав про виставку Кетрін Опі «Портрети» («Portraits», 1994), що обрамлення кожної фотографії стилізованою рамкою з яскравим кольоровим тлом перетворило ці портрети на «абстрактні знаки» й уможливило вуаєристичний погляд глядацтва (Cohen 1994, 98). Проте така оцінка випускає з уваги ефект дезорієнтації, викликаний цими портретами - суб’єкти виглядають по-королівськи у своїх ошатних декораціях, а їхні яскраві татуювання і тілесні модифікації наче створені для фотографічної слави. Глядацький погляд примушують бути схвальним і захопливим, а не об'єктивуючим та вуаєристським. Татуювання, пірсинг і тілесні модифікації моделей Опі $є$ не просто означниками ненормативності. Чи то ми дивимося на гормонально та хірургічно змінені тіла трансгендерних чоловіків, чи то на татуйовані, проколоті, шрамовані тіла буч-лесбійок, ми бачимо тіла, що демонструють свої багатошарові та множинні самовизначення.

У роботах Дела Грейса тілесна гендерна амбівалентність представлена серією портретів, виконаних у стилі Меплторпа (Robert Mapplethorpe). Але на знимках Грейса гендерну амбівалентність передано через дію, через певні форми сексуальних практик. На світлинах часто зображено два або більше тіл у взаємодії, і ґендер постає тут як результат багаторівневих перемовин між тілами, ідентичностями та бажанням. У «Тріаді» («Triad», 1992) троє голених та оголених жіночих тіл переплітаються в потрійних обіймах. Блідість тіл і шовковистість їхньої голеної шкіри створюють стійкий ефект мармуровості, перетворюють шкіру на камінь, заперечують традиційну м'якість фемінності. Грейс нерідко надає своїм героїням майже міфічного вигляду, i, як і портрети Опі, його моделі наділені гідністю, силою та красою, навіть коли він виставляє їх на огляд. 
Фотографуючи тіла бучів, Грейс використовує естетику чоловічої гей-еротики, за її допомогою створює несподіваний контекст для зображення жіночої маскулінності. У роботі «Джекова спина II» («Jack's Back II», 1994) ми бачимо спину моряка. Моряк у білих моряцьких штанях та безкозирці засуває собі руку за пояс. Потилиця акуратно підстрижена, плечі широкі та мужні. Цей образ могли висмикнути з «Кереля» Фасбіндера (Fassbinder, «Querelle», 1982) чи робіт Пола Кадмуса (Paul Cadmus), або будь-якого іншого класичного зразка гейської гомоеротики. Проте в Грейсовій роботі ми впізнаємо спину Джекі, атлетичного буча, якого Грейс знимкує нерідко. На світлині «Джекі II» («Jackie II», 1994) Джекі зображено спереду, у штанах кольору хакі, на обличчя натягнута футболка. Хоча обличчя Джекі й тепер закрите, ми бачимо її торс, і якщо наявність грудей дає змогу вважати Джекі «жінкою», то їхня форма - малі й атлетичні - підтримує образ амбівалентності.

Щоб зробити ґендер незчитуваним, Кетрін Опі теж фотографує зі спини. На світлині «Лесботка» («Dyke», 1994) ${ }^{38}$ модель стоїть на мереживному тлі спиною до авдиторії. На шиї готичним шрифтом витатуйовано «Dyke», волосся коротко підстрижене. 3 одного боку, напис на тілі однозначно застановляє - це лесбійка, проте, якщо взяти до уваги мультигендерність лесбійських портретів у виконанні Опі, слово «dyke» нічого не каже про те, як модель виглядає спереду. «Мистецтво спин» Грейса та Опі не пропонує легких загадок. Вони в прямому сенсі слова хочуть зробити гендер поверхнею для написів: слів і малюнків, мистецтва та бажання. На іншому знимку спини «Автопортрет» («Self-Portrait», 1993) Опі демонструє свою спину з гравіруванням на шкірі. По-дитячому милі дві людські фігурки-палички у спідничках тримаються за руки під хмаринкою біля будиночка, але виглядають тут геть несентиментально. Вочевидь, малюнок зроблено кров'ю, шрамування розташовано незатишно близько до одного з татуювань на руці Опі. Цей знимок перетворює спину на полотно і відводить думки в інший бік від питання, що ж там у моделі спереду. Опі так пише про цей автопортрет: «Він говорить багато про що. Наприклад, про те, що я відвернулася від вас» (Opie 1996, 30). Моделі на знимках Опі доволі часто скеровують на авдиторію свій пронизливий зворотній погляд, але не на знимках зі спини. Коли погляду не залучено (зі спини), то простір буцім є відкритим для гендерної варіативності та до можливості різних виразів остатевленого тіла.

Порізи, шрами, татуювання моделей Опі та Грейса $є$ антитезою до інших, популярних форм роботи з гендером. Знимка розмальованого тіла Демі Myp (Demi Moore) на обкладинці серпневого числа «Vanity Fair» за 1992 рік на момент виходу журналу видавалася сміливою і зухвалою. На обкладинці тіло Демі розфарбоване під чоловічий костюм, а на інших

\footnotetext{
${ }^{38}$ В англійській мові слово «dyke» $є$ сленговою самоназвою лесбійок; в українській мові «дайк» може використовуватися як і в англійській, але також позначає певну лесбійську стилістику, відмінну від буч та фем. - Прим. пер.
} 
знимках журналу вона в тому ж намальованому костюмі перехиляється через свого сонного чоловіка Брюса Вілліса (Bruce Willis). Порівняння розмальованої Демі Мур із ґендерним мистецтвом Опі та Грейса показує, як відчайдушно популярна культура прагне бути суто гетеросексуальною та ґендерноневаріативною. Мальований костюм Мур навіть приблизно не передає жіночої маскулінності передусім тому, що він чимдуж підкреслює фемінність її тіла. Якщо Опі та Грейс жодним чином не акцентують фемінність, знимки Мур зображають жіноче тіло як таке, що випромінює фемінність навіть із поверхні такого дуже традиційного маскулінного фасаду, як костюм. Для порівняння: жіноча маскулінність у роботах Опі та Грейса дає змогу побачити світ, де альтернативні маскулінності творять мистецтво гендеру.

Роботи Дела Грейса присвячено дрег-кінгам та транс-бучам, а портрети транссексуальних чоловіків Кетрін Опі звертують увагу на ще одну границю гендерної відмінності - транссексуальне тіло. У розділі 5 я вивчаю проникні кордони між бучами та транссексуальними чоловіками і намагаюся дослідити різні маскулінності, створювані в межах цих двох груп. Границя між бучами та транссексуальними чоловіками стає важливим питанням, коли ми намагаємося визначити різницю між тим, що значить «бути бучем» і «ставати чоловіком», а також «ставати транссексуалом» чи «ставати чоловіком»; у фокусі уваги в цій дискусії перебуває проект альтернативних маскулінностей у цілому. Не всі транссексуальності підважують (чи хочуть підважити) гегемонну маскулінність, але і не всі буч-маскулінності $є$ субверсивними. Але водночас транссексуальність і трансгендерність дають унікальну можливість спостерігати яскраві перформанси недомінантної маскулінності.

У цьому вступі моєю ціллю було дослідити причини і наслідки маргіналізації жіночих маскулінностей у різних сферах: з перспективи студій культури виглядає, що пригнічення жіночої маскулінності дає змогу чоловічій маскулінності зберігати за собою роль гарантки ґендерної стабільності та ґендерної відмінності. Я стверджую, що пацанки, маскулінні жінки, расовані маскулінні суб’єкти сприяють виробленню культурного імунітету до білої чоловічої маскулінності. До того ж, ґендерне поліціювання в громадських туалетах і гендерні перформанси в публічних місцях радикально змінюють ідею про правильний ґендер і вносять нові ґендери в утопійну перспективу радикально інших тіл та сексуальностей. Обстоюючи ідею гендерної транзитивності, свідомих форм жіночої маскулінності, імунітету до домінантної чоловічої маскулінності і «таксономій-оказіоналізмів», я зовсім не прагну сказати, що ми маємо, ніби за помахом чарівної палички, винайти нові набори правильних гендерів, які замінять старі форми «чоловіків» та «жінок». Я також не стверджую, буцім необхідних змін досягти легко, і що тільки-но ми, скажімо, запровадимо гендернонейтральні туалети, то домінантні режими ґендерів у гетеропатріархальних культурах зміняться. Одначе, мені видається, що вже тепер є добре відомі місця, де ґендерне дифе- 
ренціювання не працює, і те, в який спосіб гендер в який спосіб позначувальна система руйнується в цих локаціях, можна використати, щоб пришвидшити поширення альтернативних ґендерних режимів в інших локаціях. Від дрег-кінгів до шпигунів із суперпристроями, від буч-тіл до FtM-тіл, - ґендер та сексуальність, їх технології вже й тепер надзвичайно дивні. Залишилося тільки посприяти, аби вони й надалі розвивалися.

Розділи книжки розташовано не хронологічно, а за логікою втілення жіночої маскулінності. Цей вступний розділ було присвячено найочевиднішим формам жіночої маскулінності (пацанки та бучі), а також огляду методологій, але він також мав на меті показати важливість всебічно осмислювати жіночу маскулінність. У наступному розділі я намагатимусь довести, що суперечності в сучасних дискусіях довкола гендеру мають започаткувати проект з історизації жіночої маскулінності, а це, своєю чергою, мало б допомогти віднайти відповіді на питання про ґендерні суб'єктності в раніші історичні періоди. За допомогою методу, який називаю «перверсивною присутністю» [perverse presentism], я намагаюся випрацювати стратегії для розшифрування деяких прикладів жіночої маскулінності в XIX столітті і тут зосереджую увагу на «трибадках». Далі, у розділі 3, я застосовую свою квір-методологію до матеріалів XX століття і вивчаю «інверток», аби з їх допомогою дослідити середовище, у якому виник «Колодязь самотності» («Well of Loneliness», 1928). Редкліф Гол, на мою думку, не була ані унікальною у своїй маскулінності, ані покинутою напризволяще в «колодязі самотності» через свою гендерну інверсію. Я вивчаю випадки з історії, записані Гевлоком Елісом ${ }^{39}$, та газетні публікації про їі сучасниць, аби показати, що Гол була оточена спільнотами маскулінних жінок й іншими особами, що втілювали та проживали свої маскулінності в дуже різний спосіб. Форми інверсій, отже, слід розрізняти, щоб взяти до уваги варіативність цих досвідів.

У розділі 4 зосереджуся на окремій формі втілення жіночої маскулінності - стоун буч. Хоч стоун буч $є$ найвпізнаванішим серед різновидів бучності, для мене він найменш зрозумілий. Намагаючись вирішити характерну для стоун бучності суперечність між ґендером, статтю та бажанням, я відмовляюся розглядати його як приклад невдачі, коли маскулінна жінка тільки й хоче, що стати чоловіком, натомість я позиціоную стоун буч як самодостатню, свідому та повністю життєздатну суб'єктку. Стоун буч часто сприймають за перехідну ланку на шляху до трансгендерності. У розділі 5 я простежую межі між лесбійською бучністю та транссексуальними чоловіками. Що допускає жіноче втілення у випадку буча, але забороняє таке ж втілення у випадку FtM-транссексуала? Як бучі та FtM-и бачать різницю між собою? Які союзи можливі між бучами та FtM-ами?

\footnotetext{
${ }^{39}$ Гевлок Еліс (Havelock Ellis, 1859-1939) - британський учений, лікар, один із засновників сучасної сексології. - Прим. пер.
} 
Розділ 6 присвячено іншій історії бучності, кіноісторії жіночої маскулінності. У ньому я виділяю шість категорій бучів у кіно й описую ознаки та риси кожної з них. Я показую, що буч-персонажки не завжди є свідченнями голівудської гомофобії і можуть розглядатися, як приклад багатої історії квір-репрезентацій. Останнім часом, щоправда, найкращі взірці репрезентації квір-маскулінності з'являються не на екранах, а на сценах клубів, завдяки появі дрег-кінг культури. Я провів рік у клубах Нью-Йорка, Лондона та Сан-Франциско, вивчаючи форму і зміст дрег-кінг культури і в сьомому розділі опишу основні риси дрег-кінг шоу, конкурсів, кабаре та перформансів. У заключному розділі «Розлючений булл (дайк)» я роблю спробу поєднати основні теорії жіночої маскулінності, розроблені в цій книжці, й ілюструю їх за допомогою чудового зображення сердитого дайка на обкладинці книжки. У цій главі розглянуто блискучу сцену боксерського поєдинку, у якій водночас виробляється і руйнується нормативна маскулінність, а далі я перейду від «розлюченого бика» Де Ніро до булл дайка і залучу персональний наратив, який завершить це дослідження жіночої маскулінності. Чоловічий бокс - від Рокі Бальбоа (Rocky Balboa) до Джейка Ламотти (Jake LaMotta) - є для мене прикладами заскорузлого театру білої чоловічої маскулінності, яка завжди вигадає спосіб перемогти. Замінюючи цього боксера бучним розлюченим биком, я пропоную маскулінності нову чемпіонку, гідну суперницю, готову до боротьби, якій роковані перемоги.

Berger, Maurice, Wallis Brian and Watson Simon, eds. 1996. Constructing Masculinity. New York: Routledge.

Bordo, Susan. 1993. "Reading the Male Body.” Michigan Quarterly Review 32 (4): 696737.

Buford, Bill. 1992. Among the Thugs. New York: Norton.

Burke, Phyllis. 1996. Gender Shock: Exploding the Myths of Male and Female. New York: Anchor Books.

Butler, Judith. 1991. "Imitation and Gender Insubordination.” Inside/Out: Lesbian Theories, Gay Theories, ed. Diana Fuss, 13-31. New York: Routledge.

Calhoun, Cheshire. 1995. "The Gender Closet: Lesbian Disappearance under the Sign 'Women'.” Feminist Studies 21 (1): 7-34.

Cohen, Michael. 1994. "Catherine Opie - Regen Objects.” Flash Art (December): 98.

Edelman, Lee. 1994. "Tearooms and Sympathy, or The Epistemology of The Water Closet.” Homographies: Essays in Gay Literary and Cultural Studies. New York: Routledge

Epstein, Steven. 1994. “A Queer Encounter: Sociology and the Study of Sexuality.” Sociological Theory 12 (2): 188-202.

Feinberg, Leslie. 1993. Stone Butch Blues: A Novel. Ithaca, N.Y.: Firebrand.

Fung, Richard. 1991. "Looking at My Penis: The Eroticized Asian in Gay Video Porn.” How Do I look? Queer Video and Film, ed. Bad Object-Choices, 146-168. Seatle, Wash.: Bay Press.

Gagnon, John. 1994. Sex in America. Boston: Little Brown.

Garber, Marjorie. 1992. Vested Interests: Cross-Dressing and Cultural Anxiety. New York: Routledge. 
Halberstam, Judith. 1999. "Oh Bondage Up Yours: Female Masculinity and the Tomboy." Sissies and Tomboys: Gender Nonconformity and Homosexual Childhood, ed. Matthew Rottnek, 153-179. New York: New York University Press.

Hale, Jacob. 1996. “Are Lesbians Women?” Hypatia II (2): 94-121.

Hammons, Evelynn. 1997. “Toward a Genealogy of Black Female Sexuality: The Problematic of Silence.” Feminist Genealogies, Colonial Legacies, Democratic Futures, ed. M. Jacqui Alexander, Chandra Talpade Mohanty, 93-104. New York: Routledge.

Kimmel, Michael. 1996. Manhood in America: A Cultural History. New York: Free Press.

Lacan, Jacques. 1977. "The Agency of the Letter in the Unconscious.” Ecrits: A Selection, trans. Alan Sheridan. New York: Norton: 146-78.

Lewontin, R. C. 1995. “Sex, Lies and Social Science.” New York Review of Books 42 (7): 24-29.

McCullers, Carson. 1946. The Member of Wedding. New York: Bantam.

Opie, Catherine. 1996. “Catherine Opie with Russel Ferguson,” interview by Russel Ferguson, Index. April: 28-31.

Pagel, David. 1994. “Catherine Opie.” Art Issues. September/October: 45.

Patton, Cindy. 1993. “Tremble Hetero Swine.” Fear of Queer Planet: Queer Politics and Social Theory, ed. Michael Warner, 143-177. Minneapolis: University of Minnesota Press.

Pheil, Fred. 1996. “A Buffalo, New York Story.” Boys: Masculinities in Contemporary Culture (Cultural Studies), ed. Paul Smith, 9-22. Boulder, Colo: Westview Press.

Plummer, Ken and Stein Arlene. 1994. "I Can’t Even Think Straight: Queer Theory and the Missing Revolution in Sociology.” Sociological Theory 12 (2): 178-187.

Rodriguez, Nice. 1993. Throw It to the River. Toronto: Women's Press.

Seidler, Victor J. 1994. Unreasonable Men: Masculinities and Social Theory. New York: Routledge.

Smith, Anna Marie. 1991. “The Feminine Gaze: Photographer Catherine Opie Documents a Lesbian Daddy/Boy Subculture.” The Advocate. 19 November: 82-83.

Smith, Paul, ed. 1996. Boys: Masculinities in Contemporary Culture (Cultural Studies). Boulder, Colo: Westview Press.

Wittig, Monique. 1990. “The Straight Mind.” Straight Mind: Collected Essays, 21-32. New York: Routledge. 